\title{
SHORT NOTES ON ALASKAN GEOLOGY
}

1979-80

GEOLOGIC REPORT 63

Recent research on Alaskan geology

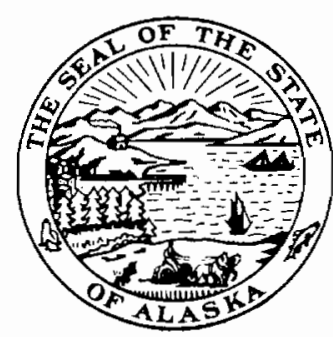




\section{STATE OF ALASKA}

Jay S. Hammond, Governor

Robert E, LeResche, Commissioner, Dept. of Nalural Resaurces

Geoffrey Haynes, Deputy Commissioner

Ross G, Schair, Slate Geologist

\section{'Short Note' Editorial Policy}

This document comprises short contributions on recent investigations of a fimited scope on Alaskan geology. Manuscripts are accepted lor review with certain qualifica. tions: that manuscripts must not have been published or submitted for publication else where; that all persons listed as authors have given their approval for submission of the paper; and that any person cited as a source of personal communication has approved such a citation.

Two copies of the manuscripl, typed double spaced including relerences and figure captions, should be submitted lo Fiditor, Alaska Division of Geological \& Geophysical Surveys, Box 80007, College, AK 99708. No more than seven double-spaced manuscript pages (2000 words), including references, figures, and tables, will be accepted. All figures should be camera ready and suitable for black-and-white reproduction at maximum size of $6-1 / 2$ by $8-1 / 2$ inches-toldout or color art will not be accepted. Cantributors should keep one copy of material submitted. All manuscripts will be examined and approved by Alaska DGGS reviewers. Substanlial changes by the authar whether scientific or editorial-will not be allowed once the manuscript is in galley form.

Deadline for manuscripts for the next Short Notes on Alask a Geology is May 1, 1981.

Cover photo: Active(?) rock glacier, headwaters of Ganes Creek, Iditarod Quadrangle, Alaska.

Fox sale by Alastea Division of Geological and Geophysical Surveys, P.O. Box 80007, College, 99708: 941 Dowling Rd., Anchorage, 99503: P,O. Box 2488, Ketchikan, 99901 : and 290 S. Franklin. Juneau, 9981 I. Cost: $\$ 1.00$. 


\section{CONTENTS}

Pagc

Lead isotope ratios from the Red Dog and Drenchwater Creck lead-zinc deposits, De Long

Mountains, Brooks Range, Alaska, by Larry Lueck . . . . . . . . . . . . . . . . . . . . . . . . .

40K-40 Ar ages from thyolite of Sugar Loaf Mountain, central Alaska Range: Implications for of iset along the Hines Creek strand of the Denali faull system, by Mary D. Albanese and Donald L. Turner ..... . 7

Multiple glaciation in the Beaver Mountains, western interior Alaska, by T.K. Bundtzen . . . . . . . . . . . . 11

Fossil algae in Lower Devonian limestones, east-central Alaska, by James G. Clough . . . . . . . . . . . . . . . 19

Tertiary tillites(?) on the northeast Ilank of Granite Mountain, central Alaska Range, by L. David Carter . . . . . . 23

Evidence for supiapermafrost grounci-water blockage, Prudhoe Bay oil field, Alaska, by Gail D. March . . . . . . 29

\section{METRIC CONVERSION FACTORS}

To convert feel to meters, multiply by 0.3048 . To convert inches to centineters, multiply by 2.54 . 


\title{
LEAD ISOTOPE RATIOS FROM THE RED DOG AND DRENCHWATER CREEK LEAD-ZINC DEPOSITS, DE LONG MOUNTAINS, BROOKS RANGE, ALASKA
}

\author{
By Larry Lueck ${ }^{1}$
}

\section{INTRODUCTION}

New lead isotope data have been determined for the Red Dog and Drenchwater Creek base-mecal sulfide occurrences in the De Long Mountalns of the western Brooks Range, Alaska. To the author's knowledge these are the only two deposits studied by lead isotope methods on the north flank of the Brooks Range.

The Red Dog Prospect (secs. 20 and 29, T. 31 N., R. 18 W., Kateel River Meridlan, De Long Mountains Quadrangle), was first descrlbed by Tailleur (1970). Mineralization occurs primarily as disseminations of sphalerite, pyrite, and milnor galena in country rock; as quartz-rich veins and podlform bodies of zinc, lead, and iron sulfides, some of which contain barite; and as extensive overlying massive barite of unknown configuration. Origin of the mineralization is a matler of considerable debate.

About $160 \mathrm{~km}$ east of Red Dog is Drenchwater Creek (T. 10 S., R. 1 E., Umiat Meridian, Howard Pass Quadrangle), the site of an apparently low-grade, disseminated lead-zinc deposit in volcanic, intrusive, and pelagic sedimentary rocks that have been complexly disturbed by folding and low-angle thrusting. Prcvious investigators believe the mineralization may be volcano. genic-exhalative in origin and therefore contemporaneous with the country rock.

Local geology and structure are presented by Plahuta (1978) and Nokleberg and Winkler (1978) for the Red Dog and Drenchwater Creek deposits, respectively. Soil geochemistry and results of magnetometer and gamma-ray spectrograph surveys of bolh deposits are reported by Metz and others (1978a).

\section{DATA}

Two samples from Red Dog vein material and one sample from Drenchwater Creek disseminated ore were chosen for this study. Two galena splits from each sample were hand separated by the author and analyzed by Teledyne Isotopes, Inc., of New Jersey and Dr. G.L. Cumming of the University of Alberta, Edmonton. Dilferent methods of lead digestion and concentration were used by Teledyne and Cumming, but both sets of analyses were normalized according to the NBS981 lend

\footnotetext{
${ }^{1}$ DGGS, College, AK 99708
}

standard and gave good reproducibility (L.F. Casabona and G.L. Cumming, written comm., 1979\}.

Results are listed in table 1 and the ratios are plotted in figures 1 and 2 , which are graphs of $207 \mathrm{~Pb} / 204 \mathrm{~Pb}$ vs $206 \mathrm{~Pb} / 204 \mathrm{~Pb}$, and $208 \mathrm{~Pb} / 204 \mathrm{~Pb}$ vs $206 \mathrm{~Pb} / 204 \mathrm{~Pb}$. These graphs contain: a) a 'lead growth curve' that shows gradual decay of uranium or thorium to stable lead isotopes through time and b) a series of 'isochrons' that radiatc from an estimated primordial lead composition and cross the growth curve in increments of years before present. Dato points on or near the growth curve are, in theory, dated by the isochron crossing the curve al that point. More thorough discussions of thorium and lead decay are found in Doe (1970), Doe and Stacey (1974), and Faure (1977, p. 227-66). Stacey and Kramers (1975) and Cumming and Richards (1975) describe new growth curves that are based on fewer assumptions and better lit the lead isotope data than do the old single-stage models. Together with Richards (1971), these papers present the most thorough examination of current research in lead isotope theory. On the advice of Cumming (pers. comm., 1980), the Stacey and Kramers (1975) model growth curve is used in this paper because it best approximates relatively young leads such as those of the Red Dog and Drenchwater Croek deposits.

A line of best fit through the reledyne data points (fig. 2) passes very close to the origin of the graph, which indicates there are probably signiflcant $204 \mathrm{~Pb}$ errors in these analyses (Kanesewich, 1968, p. 155-60). Because $204 \mathrm{~Pb}$ constitutes less than 1.65 percent of any natural lead, its analysis is difficult (Cannon and others, 1961 , p. 5 ); nevertheless, these probable errors render the Teledyne points unreliable for dating. The Cumming data points fall close to this same $204 \mathrm{~Pb}$ error line, but their tight grouping indicates that the $204 \mathrm{~Pb}$ error is not very significant in these analyses. All three points plot close to the Stacey and Kramers (1975) growth curve. Within the limits of analytical error, they are the same (table 1 and fig. 1) and remain Logether, even on the larget scale plot of $207 \mathrm{~Pb} / 204 \mathrm{~Pb}$ vs $206 \mathrm{~Pb}$ / $204 \mathrm{~Pb}$ (fig. 2). Hence, unless three almost identical samples have accidentally been selected from two otherwise heterogeneous populations (a possibility discussed 
Table 1. Lead isolope ralios from the Red Dog and Drenchwaler Creck deposits

\begin{tabular}{|c|c|c|c|c|}
\hline Sample & $206 / 204$ & $207 ! 204$ & $208 / 204$ & References \\
\hline LL. 26-18 (Red Dog) & $\begin{array}{l}18.404 \pm .013 \\
18.175 \pm .000\end{array}$ & $\begin{array}{l}15.590 \pm .014 \\
15.414 \pm .037\end{array}$ & $\begin{array}{l}38.228 \pm .046 \\
37.770 \pm .091\end{array}$ & $\begin{array}{l}1 \\
2\end{array}$ \\
\hline LL-4-14(Red Dog) & $\begin{array}{l}18.413+.016 \\
18.325 \pm .000\end{array}$ & $\begin{array}{l}15.604 \pm .017 \\
15.535 \pm .012\end{array}$ & $\begin{array}{l}38.197 \pm .062 \\
38.026 \pm .035\end{array}$ & $\begin{array}{l}1 \\
2\end{array}$ \\
\hline 78PMO52 (Drenchwater) & $\begin{array}{l}18.406 \pm .018 \\
18.057 \pm .000\end{array}$ & $\begin{array}{l}15.593 \pm .013 \\
15.353 \pm .045\end{array}$ & $\begin{array}{l}38.270 \pm .049 \\
37.585 \pm .105\end{array}$ & $\begin{array}{l}1 \\
2\end{array}$ \\
\hline $\begin{array}{l}\text { Siacey and Kramers' average } \\
\text { modern lead }\end{array}$ & 18.700 & 15.628 & 38.63 & 3 \\
\hline \multicolumn{5}{|c|}{$\begin{array}{l}\text { 1. Analyses [rom G.L. Cumming laboratory, University of Alberta, Edmonton. } \\
\text { 2. Analyses from Teledyne Isotopes, Inc. } \\
\text { 3. Stacey and Kramers, } 1975 \text {. }\end{array}$} \\
\hline
\end{tabular}

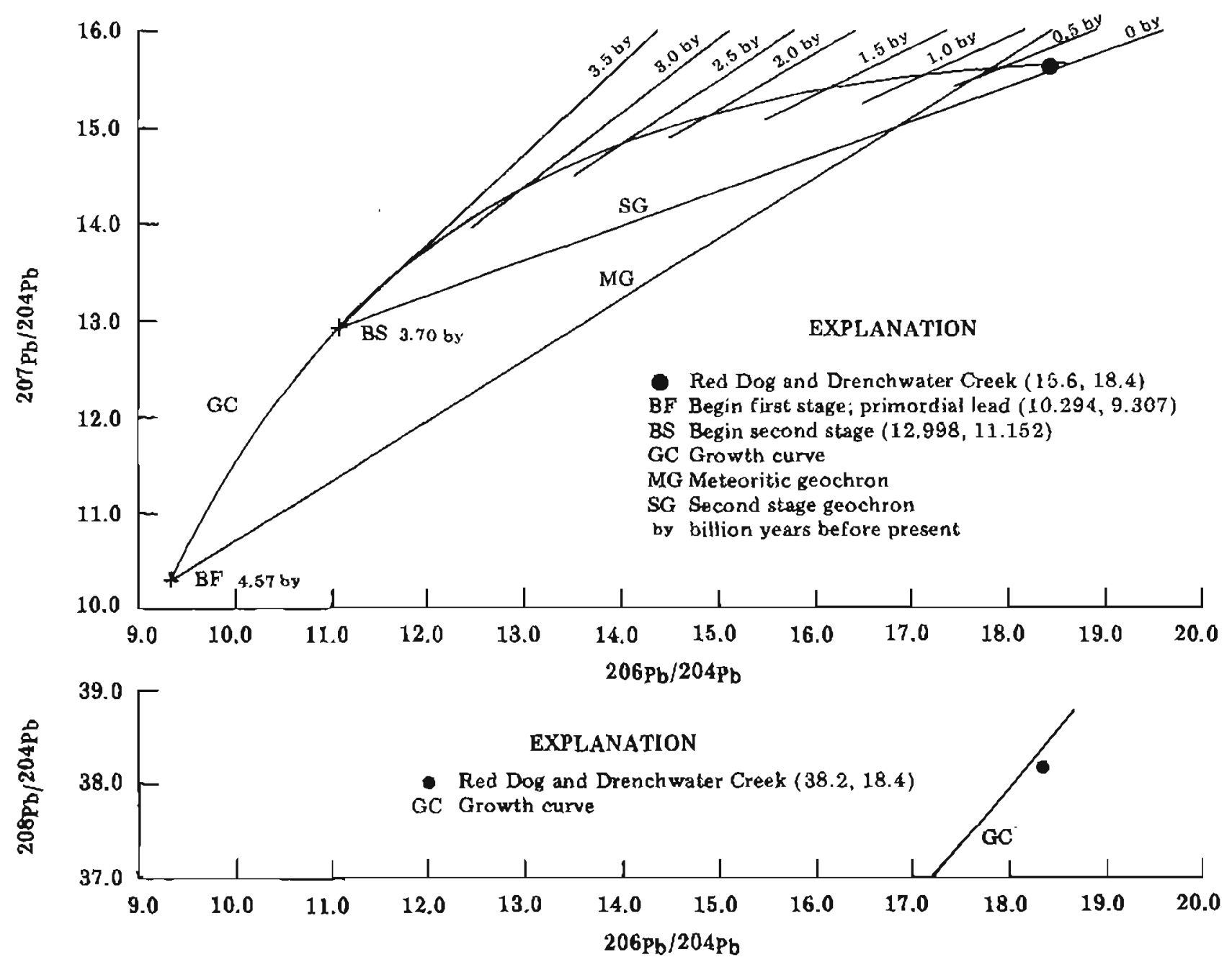

Figure 1. Two-stage model of Stacey and Kramers (1975) plothed with Red Dog and Drenchwater Creek data. 
below), the two deposits probably received this lead from the same source or from two genetically related sources.

\section{BACKGROUND}

'Ordinary' leads are thought to be derived from a deep, homogeneous source without much crustal contamination. These leads may give meaningful model dates in some cases bul are fairly rare. Relatively lew deposits contain lead with isotope ratios similar enough to an ideal growth curve to be classed as ordinary and thus datable by $\mathrm{Pb} / \mathrm{Pb}$ methods (Cumming and Richards, 1975, table 3, p. 165; Stacey and Kramers, 1975 , tables 2, 4, and 6, p. 208, 210, and 213). Samples trom modern volcanogenic and exhalative deposits do not necessarily plot on the zero isochron, or 'geochron.' Therefore, some investigators believe that even oceanic volcanic rocks have been contaminated by crustal, radiogenic lead (Richards, 1971, fig. 3, p. 429). Thus, even those lead isolope ralios presumed to be ordinary must be cautiously interpreted with regard to other geologic evidence.

All leads that are not ordinary are lermed 'anom. alous.' Although quite random combinations of lead isotope ratios can be found in anomalous deposits, two special catcgories have been recognized, 'B-type' and 'J-type.' In the former, lead has a model age greater than that of the host rock, a condition thought to be caused by remobilization and redeposition of older crustal lead in younger country rock. J-type lead deposits are produced by mixing of older crustal lead with juvenile lead from depth and often yield negative, or future, model ages.

Base-metal deposits containing anomalous leads yield such age discrepancies (that is, if age can be estimated al all) and exhibit a wide scatter of isotope ratios (Stanton and Russell, 1959, p. 595). In the Mississippi Valley and Tri-State districts, where anomalous j-type leads are common, the scalter is even more pronounced (Heyl and others, 1974, fig. 2, p. 995). On the other hand, the isolopic similarity of 3eads from the Red Dog and Drenchwaler Creek deposits suggests that these leads are ordinary. Furthermore, as shown above, these analyses fall close to an ideal growth curve for ordinary lead (fig. 2).

\section{ALTERNATIVES IN EVALUATING THE DATA}

Leads from only three galena samples from the Red Dog and Drenchwater Creek deposits were analyzed for this study. If these samples are not representative of those deposits, then the data are not significant, the leads could be either ordinary or anomalous, and their dalability and other properties are left in question.

If, on the other hand, the samples do represent the deposits, then the leads are probably ordinary and thereforc dalable. On Stacey and Kramers' (1975) leadgrowth curve the sample analyses yield a lead model mineralization age of about $170-190 \mathrm{~m} . \mathrm{y}$. (fig. 2). This Early Jurassic age is corroborated by Lange and others (1980), who report an age of $200 \mathrm{m.y}$. for galena mineralization at Red Dog (although the ralios and model used to determine this age are not reported).

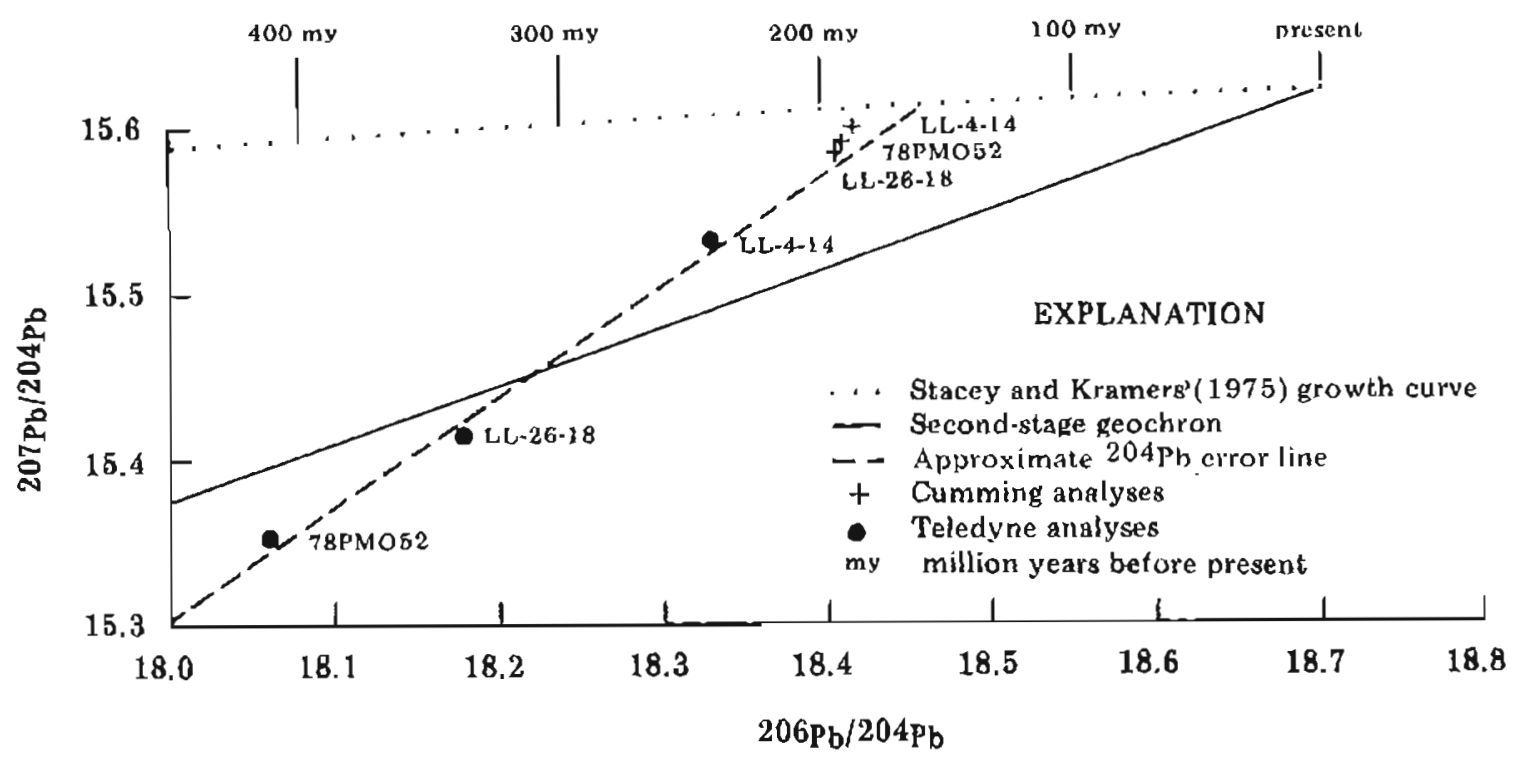

Figure 2. Enlargenent of upper end of growth curve shown in figure 1. 


\section{DISCUSSION}

'Though of unproven stratigraphic position, host rock for the Red Dog ore is mainly silicified black mudstone, shale, and chert and contains disseminated sulfides. It has been assigned by Plahula (1978, fig. 2, p. 4-5), to the Tupik Formation, which is the uppermost formation of the Mississippian Lisburne Group and part of the De Long Sequence of Martin (1970, fig. 2b). The unit has yielded no direct fossil or K-Ar dates at Red Dog, but chert samples collected by the author and co. workers from strata immediately overlying the ore zone contain radiolaria (identilied by D.L, Jones, USGS) of Permian age (Nokleberg, pers. comm., 1980). Assuming, therefore, that the country rocks are Permian or older, a Jurassic $\mathrm{Pb} / \mathrm{Pb}$ age of $170-190$ m.y. is reasonable for the discordant vein mineralization, but not for the disseminated ore, which is probably syn. genetic. Thus, at least two stages of mineralization, widely separated in time, may be represented in the Red Dog deposit.

Biotites from a keratophyre and a pyroxene andesite from the Drenchwater Creek occurrence yielded K-Ar ages of $319 \pm 10 \mathrm{my}$. and $330 \pm 17 \mathrm{m.y.}$, respectively ('Taisleur and others, 1977). Sample 78PMO52 ylelded a lead age of 170-190 m.y. and was collected from the unit designated by Nokleberg and Winkler (1978, pl. 1) as the 'black, medium-bedded chert' of the Mississipplan Lisburne Group. These rocks include abundant volcanics and intrusives not found at Red Dog, but are thought to be tateral facies equivalcnts of the black host rock at Red Dog. Nokleberg and Winkler (1978, p. 13) state that galena and sphalerite of the Drenchwater Creek deposit are closely associated with aquagene tuff (the keratophyre and pyroxene andesite) or with dark chert and shaje adjacent to tuff. Hence, the mineralization could be largely syngenetic and volcanogenicexhalative, and therefore Mississippian, as is the host rock. However, a previously unrecognized mineralizing event may lave introduced epigenetic galena 170.190 m.y. ago. Pervasive thrusting and folding that continued along the North Slope through Cre laceous lime (Nokleberg and Winkler, 1978, p. 10) may have obscured or destroyed evidence of the mode of this lead emplace. ment. No such evidence was recognized during field work (but there was no suspicion of two generations of lead at that time).

Thus, lead isotope ratios from the Red Dog and Drenchwater Creek deposits, if signiffcant, provide evidence for a Jurassic epigenetic mineralizing event, although other geological evidence points to an earlier Mississippian perjod of syngenetic ore deposition.

There is mounting evidence that during Mississippian time a large-scale rift, or aulacogen, opened along an east-west axis through the present North Slope of Alaska (Metz and others, 1978b). Volcanic and sub. marine exhalative activity accompanying the rifting probably produced the Mississippian base-metal sulfide deposits syngenetically in pelagic sediments filling this trough. The later mineralization might have occurred during overthrusting of oceanic crust onto the Brooks Range rocks, which began in Jurassic time, when rifting reversed itself to assume a compressional mode that persisted into Early Cretaceous time, as described by Roeder and Mull (1978, p. 1701).

Several cases of recurrent or continuous mineralization over periods of up to $300 \mathrm{~m} . \mathrm{y}$. are discussed in Smirnow (1977), Frequent or continuous ore deposition over a long time would probably produce a sel of tead ratios difficult to distinguish from the random scacter of a Mississippi Valley-type deposit. This problem need not be handled here, however, because available geologic and lead isotope data indicate only two periods of mineralization at the Red Dog and Drenchwater Creek deposits, not a continuum.

As Smirnow (1977) emphasizes, the stylc and mech. anism of ore emplacement cannot be expected to remain unchanged over these spans of time. If tectonic activity is renewed or continued along a given trend, for in. stance. a plate boundary, the style of tectonism-and thus the type of mineralization-will probably vary. Because the North Slope has been the locus of tectonic activity for at least $150 \mathrm{~m} . \mathrm{y}_{\text {, t }}$ two or more genetically different types of mineralization may be superimposed at the Red Dog and Drenchwaler Creek deposits.

Mitchell and Garson (1976) discuss processes for emplacement of lead-zinc sulfide deposits under both divergent and convergent plate regimes that could produce a twofold mineralization like that postulated here. Type-identified ore deposits have been used in reconstructions of the plate tectonic history of numerous regions. For example, Metz and others (1978b) have reconstructed a history of the North Slope region of Alaska that relies heavily on the occurrence of ore deposits. But to be useful, such deposits must be correctly identified as to type. Incorrect characteriza. tion of the deposit type at either Red Dog or DrenchWater Creek would be highly misleading.

\section{CONCLUSIONS}

a) Samples selected from the deposits at the Red Dog and Drenchwater Creek occurrences have nearly identical lead isotope ratios. If these samples are not representative of lead in the deposits, the resemblance of ratios is merely a coincidence. But if the samples are typical of the deposits, then the lead is ordinary rather than anomalous, and therefore datable.

b) Available lead isotope ratios yield Jurassic ages of 170-190 m.y. For galena samples from both the Red Dog and Drenchwater Creek occurrences. Other evidence yields a Mississippian age for the host rock and syngenetic sulfides at both locations. This difference in ages is best explained by the occurrence of two mineral- 
izing events, widely separated in time-in which case there may well be two different types of mineralization at the Red Dog and Drench water Creek deposits.

\section{ACKNOWLEDGMENTS}

Grateful acknowledgment is made of financial support from the Geology and Geophysics Program and the Department of Mineral Engineering of the University of Alaska, Fairbanks. Special thanks are due Dr. G.L. Cumming of Edmonton for the analyses he performed, and for much friendly advice. Mark S. Robinson and John $T$. Dillon critically reviewed the manuscript and offered many helpful suggestions.

\section{REFERENCES CITED}

Cannon, R.S., Jr., Pierce, A.P., Anlweiler, J.C., and Buck, K.L., 1961, The data of lead isotope geology related to problems of ore genesis: Econ. Geology, v. 56, p. $1-88$.

Cumming, G.L., and Richards, J.R., 1975, Ore lead isotope ratios in a continuously changing Earth: Earth and Planetary Sci. Letters, v. 28, p. 155-71.

Doe, B.R., 1970, Lead isotopes: New York, SpringerVerlag, $137 \mathrm{p}$.

Doe, B.R., and Stacey, J.S., 1974, The application of lead isotopes to the problems of ore genesis and ore prospect evaluation: A review: Econ. Geology, v. 69, p. 757.76 .

Faure, Gunter, 1977, Principles of isotope geology: New York, John Wiley, $464 \mathrm{p}$.

Heyl, A.V., Landis, G.P., and Zartman, R.E., 1974, Isotopic evidence for the origin of Mississippi Valleytype mineral deposits: A review: Econ. Geology, v. 69, p. 992-1006.

Kanasewich, E.R., 1968, The interpretation of lead isotopes and their geological signilicance, in Hamilton, E.I., and Farquhar, R.M., eds, Radiometric dating for geologists: New York, Interscience, 506 p.

Lange, I.M., Nokleberg, W.J., Plahuta, J.T., Krouse, H.R., Doe, B.R., and Jansons, Uldis, 1980, Geochemistry of volcanogenic $\mathrm{Zn}-\mathrm{Pb} \cdot \mathrm{Ba}$ deposits, NW Brooks, Alaska: Geol. Soc. America Abs. with Programs, Cordilleran Section, v. 12, no. 3, p. 116.

Martin, A.J., 1970, Structure and tectonic history of the western Brooks Range, De Long Mountains, and Lisburne Hills, northern Alaska: Geol. Soc. America Bull, v. 81 , p. 3605-22.
Metz, P.A., Rabinson, M.S., and Lueck, Larry, 1978a, Baseline geochemical studies for resource evaluation of D-2 lands - Creophysical and geochemical investigations of the Red Dog and Drenchwater Creek mineral occurrences: Fajrbanles, Mineral Industry Research Laboratory, Fairbanks, University of Alaska, unpub. rept. Lo the U.S. Burcau of Mines, $21 \mathrm{p}$.

Metz, P.A., Robinson, M.S., Peace, J.L., and Lueck, Larry, $1978 \mathrm{~b}$, Carboniferous metallogeny of the northern Brooks Range, Alaska: Geoscience Forum, 6th, Whitehorse, Yukon Territory, 1978, unpub.

Mitchell, A.H.G., and Garson, M.S., 1976, Mineralization at plate boundaries: Minerals Sci. Eng., v. 8 , p. 129.69.

Nokleberg, W.J., and Winkler, G.R., 1978, Geological setting of the lead and zinc deposits, Drenchwater Creek area, Horward Pass Quadrangle, western Brooks Range, Alaska: U.S. Geol. Survey Open-file Rept. 78-700, $16 \mathrm{p}$.

Plahuta, 3.T., 1978, Geological map and cross sections of the Red Dog Prospect, De Long Mountains, northwestern, Alãska: U.S. Bur. Mines Open-file Rept. 65-78,11 p.

Richards, J.R., 1971, Major lead ore bodies - mantle origin?: Econ. Geology, v. 66, p. 425-34.

Roeder, Dietrich, and Mull, C.G., 1978, Tectonics of Brooks Range ophiolites, Alaska: Am. Assoc. Petroleum Ceologists Bull., v. 62, p. 1696-1713.

Smirnow, V.J., 1977, Factor of time in Formation of stratabound ore deposits, in Klemm, D.D., and Schneider, H.J., (eds.), Time- and strata-bound ore deposits: New York, Springer-Verlag, $444 \mathrm{p}$.

Stacey, J.S., and Kramers, J.D., 1975, Approximation of terrestrial lead isotope evolution by a two-stage model: Earth and Planetary Sci. Letters, v. 26, p. 207.21

Stanton, R.L., and Russell, R.D., 1959, Anomalous leads , and the emplacement of lead sulfide ores: Econ. Geology, v. 54, p. 588-607.

Tailleur, 1.L., 1970, Lead-, zinc-, and barite-bearing samples from the western Brooks Range, Alaska, with a section on petrology and mineralogy by G.D. Eberlein and Ray Wehr: U.S. Geol. Survey openfile rept., $16 \mathrm{p}$.

Tailleur, I.L., Ellersieck, I.F., and Maycield, C.F., 1977, Mineral resources of the western Brooks Range, in Blean, K.M., United Stales Geological Survey in Alaska: Accomplishments during 1976: U.S. Geol. Survey Circ. 75 J-B, p. 24-25. 



\title{
$40 \mathrm{~K}$-40 Ax AGES FROM RHYOLITE OF SUGAR LOAF MOUNTAIN, CENTRAL ALASKA RANGE: IMPLICATIONS FOR OFFSET ALONG THE HINES CREEK STRAND OF THE DENALI FAULT SYSTEM
}

\author{
By Mary D. Albanese ${ }^{1}$ and Donald L. Turner ${ }^{2}$
}

\section{INTRODUCTION}

Sugar Loaf Mountain is located $6 \mathrm{~km}$ north of the Hines Creek strand of the Denali [ault system at lat $63^{\circ} 47^{\prime} \mathrm{N}$, long $148^{\circ} 50^{\prime} \mathrm{W}$. , and consists of rhyolite intruded by andesite. The rhyolite overlies a basement of mica-quartz schist of possible Precambrian to early Paleozoic age. Mineralogically similar masses of rhyolite and andesite intrude the underlying schist up to $4 \mathrm{~km}$ south of Sugar Loaf Mountain (fig. 1).

The Hines Creekstrand trends east-west and separates the previously mentioned mica-quartz schist from the more southerly Paleocene Cantwell Formation. Wahrhaftig and others (1975) estimate 65 to $315 \mathrm{~km}$ of lateral displacement along the Hines Creek strand between De. vonian and Cretaceous time. The Cantwell Forma tion is intruded by mafic dikes leeding the volcanic Teklanika Formation (Bultman, 1972; Wahrhaftig and others, 1975; Gilbert and others, 1976).

Volcanic rocks of the Teklanika Formation (sample localities $40 \mathrm{~km}$ west of Sugar Loaf Mountain) yielded $40_{\mathrm{K}-40}$ Ar ages of $41.8 \mathrm{m.y} ., 57.2 \pm 3.1 \mathrm{~m} . \mathrm{y}$., and 60.6 m.y. (Gilbert and others, 1976). Hornblende from basaltic andesite of the 'Teklanika Formation at Mount Fellows ( $9 \mathrm{~km}$ southeast of Sugar Loaf Mountain) yielded a ${ }^{40} \mathrm{~K}-{ }^{40} \mathrm{Ar}$ age of $49.5+2.1 \mathrm{~m} . \mathrm{y}$. (Bultman, 1972). This can be interpreted as a minimum age because the dated rock was altered.

Rhyolite and andesite of the Sugar Loaf Mountain area have been interpreted as part of the Teklanika Formation (Gilbert, 1979). The proximity of similar volcanic rocks north and south of the Hines Creek strand led Buttman (1972) to suggest that lateral motion along the strand has been minimal since Paleo. cene time. However, $40_{\mathrm{K}} 40_{\mathrm{Ar}}$ whole-rock ages of the Sugar Loaf Mountain rhyolite reported here do not support this interpretation.

\section{${ }^{40} \mathrm{~K}-40_{\mathrm{Ar}}$ AGE DETERMINATIONS}

Four whole-rock samples of fine-grained thyolite from the Sugar Loaf Mountain area (fig. 1) were dated

\footnotetext{
${ }^{1}$ DGGS, College, AK 99708

${ }^{2}$ Geophysical Institute, University of Alaska, Fairbanks, AK 99701
}

by the $40_{\mathrm{K}} \cdot 4 U_{\mathrm{Ar}}$ method at the Geochronology Labora. tory of the Geophysical Institute, University of Alaska, Fairbanks (table 1). Samples MIR78-2 and -39 are from an outcrop on Sugar Loaf Mountain, and samples MR78. 50 and -58 are from localities 4.0 and $1.2 \mathrm{~km}$ southeast of the mountain, respectively. The petrology of these samples is listed in table 2. Samples MR78-39, -50, and .58 ineet petrologic criteria from reliable ages (Mankinen and Dairymple, 1972). Although sample MR78.2 contains devitrified groundmass glass, its age agrees with those of the other samples. These rhyolites yield middle Oligocene whole-rock ages ranging from $32.4 \pm 1$ to $35.2 \pm 1 \mathrm{~m} . y$. (table 1 ). Field relationshjps suggest that the associated andesite is contemporaneous or younger (Albanese, 1980).

\section{DISCUSSION AND CONCLUSIONS}

The substantial age difference between the dated Teklanika Formation andesite in the Mount Fellows region (Bultman, 1972) and the dated rlyolite in the Sugar Loaf Mountain area indicates that the rocks of the two regions are not genetically relaled. Thus, they provide no evidence on the dates or amounts of displacement along the Hines Creek strand. The main geologic constraint on the age of the strand is the Buchanan Pluton, located about $70 \mathrm{~km}$ east of Sugar Loa Mountain. This intrusive body has been dated at $95 \mathrm{~m} . \mathrm{y}$. and extends northeast across the trace of the Hines Creek strand with no offset, which suggests the absence of lateral movement along the Hines Creek strand in the last $95 \mathrm{my}$.

The only known rhyolite and andesite bodies south of the Hines Creek strand that can be correlated with those of the Sugar Loaf Mountain area are the midTertiary Pelsic volcanic rocks that form a subordinate part of the Mount Gaten Volcanics. This formation, located south of the Hines Creek strand and about $60 \mathrm{~km}$ southwest of the Sugar Loaf Mountain area, is predominantly andesite and basall and yields $40_{\mathrm{K}-40} \mathrm{Ar}$ ages ranging from $32.3 \pm 1.0$ to $43.2 \pm 2.6 \mathrm{~m}$.y. (Decker and Gilbert, 1978). Mid-Tertiary felsic intrusives also occur north and south of the Mount Galen Volcanies (Gitbert, 1979). Although the Mount Galen Volcanics are about the same age as the rhyolite and andesite of the Sugar Loaf Mountain area, the two volcanic se- 


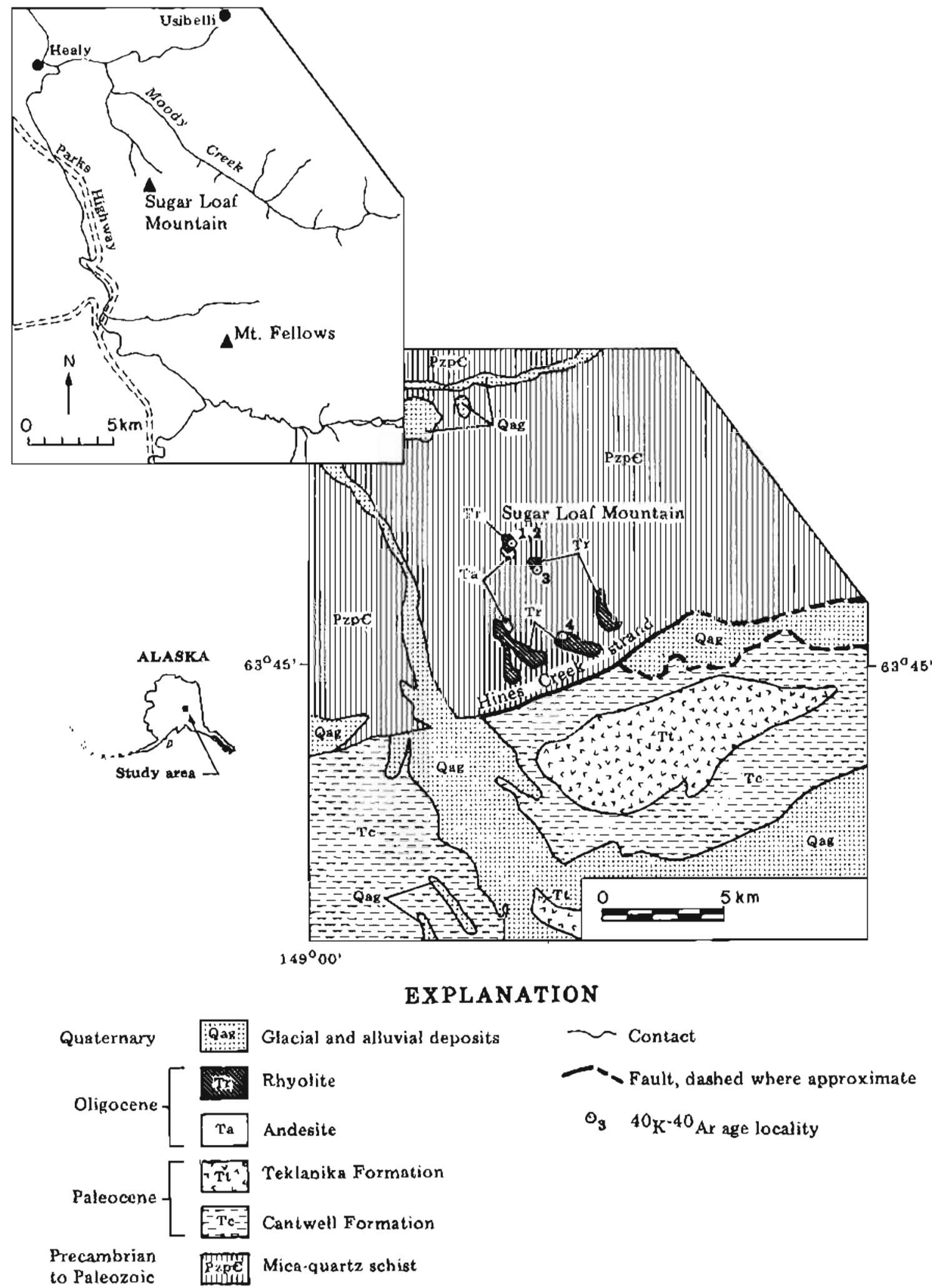

Figure 1. Location and generalized geologic map of Sugar Loaf Mountain area. Geology from Albanese (1980), Bultman (1972), Gilbert (1979), and Wahrhaftig (1970). 
Table 1. Anulytical data for whole-rock K-Arage determinations on rhyolites from Sugar Loaf Mountain area.

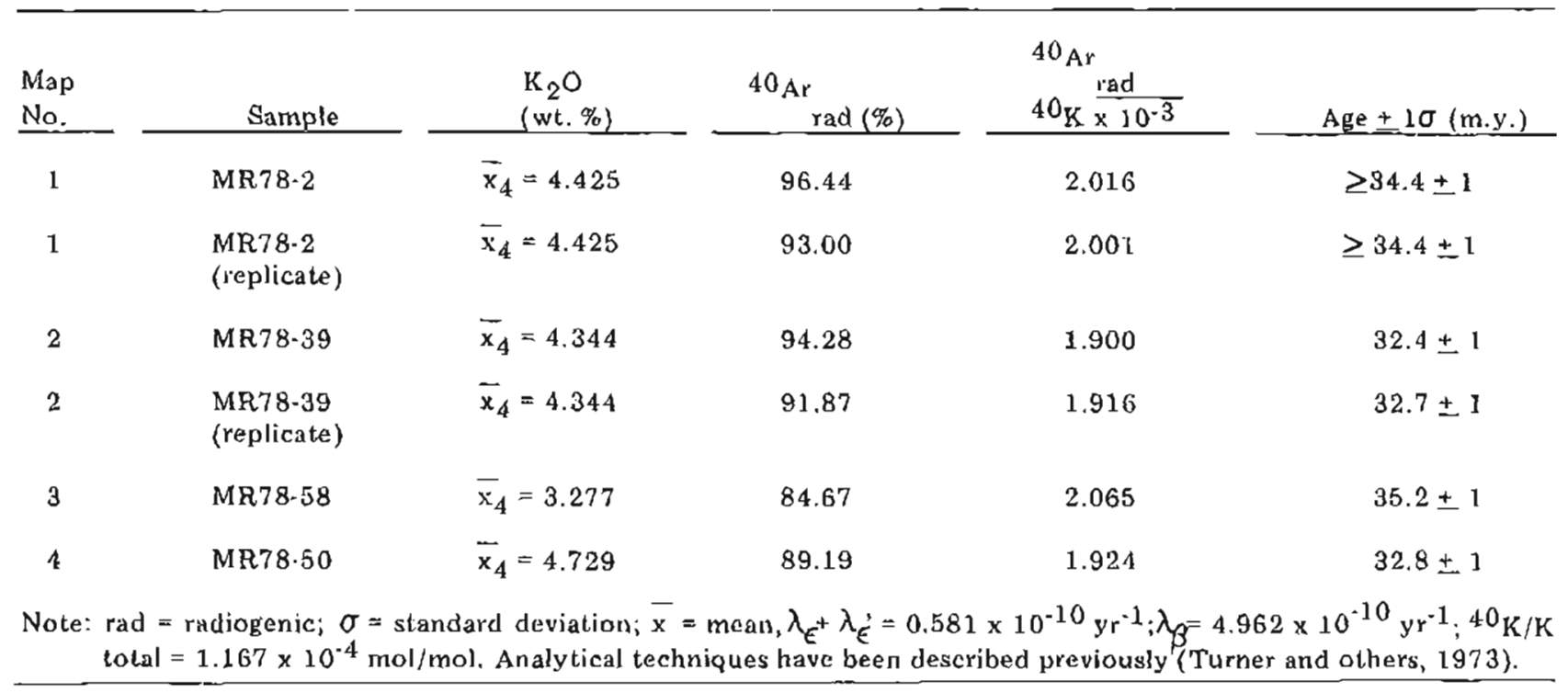

quences differ in age composition and may not be genetically related. However, igneous suites from both areas were probably produced during the same mid. Tertiary regional magmatic event.

'Tuble 2. Pelrology of rhyolites from Sugar Loas Mountesin area.

MR78.2

Phenocyysts - 5\% quarty $(0.5 \cdot 2 \mathrm{~mm}$ dia $)$ $5 \%$ alkali feldspar (0.5-1 $\mathrm{mm}$ dia) 18 plagioclase $(0.5 \mathrm{~mm}$ clia $)$

Groundmass - 68\% quartz $20 \%$ devitiriried glass 1\% hypersihene

$\operatorname{MIR78.39}$

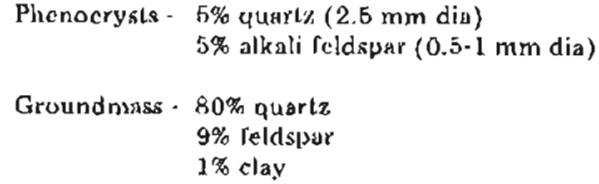

Phenocrysts - 5\% quart\% (2.5 mm dis) $5 \%$ alkali reldspar (0.5-1 mm dia)

Groundniass . $80 \%$ quartz $9 \%$ reldspar $1 \%$ clay

MR78.50

Phenocrysis - $1 \%$ alkali leldspar ( $\mathrm{mm}$ dia)
$\begin{aligned} & \text { Groundniass }- 79 \% \text { quarlz } \\ & 17 \% \text { feldspar } \\ & 2 \% \text { clay } \\ & 1 \% \text { sericile }\end{aligned}$

MR78-58

\begin{tabular}{|c|c|}
\hline Plienocrysts & $\begin{array}{l}5 \% \text { quarte }(2.5 \mathrm{~mm} \text { dia) } \\
5 \% \text { alkali (clds(s)ar }(0.5 \cdot 1 \mathrm{~mm} \text { dia) }\end{array}$ \\
\hline Groundmass & $\begin{array}{l}80 \% \text { quartz } \\
9 \% \text { reldspar } \\
1 \% \text { clay }\end{array}$ \\
\hline
\end{tabular}

\section{ACKNOWLEDGMEN'TS}

This project was funded by U.S. Dept. of Energy contract EW-78-5-07-1720. Field assistance was pro. vided by Harriet Small. Technical assistance with $40 \mathrm{~K}$ 10 Ar measurements was provided by Barry Spell. The authors thank W.G. Gilber and T.K. Bundzzen of DGGS and Samuel Swanson of the University of Alaska ,for their thoughtful reviews.

\section{REFERENCES CI'TED}

Albanese, M.D., 1980, The geology of three extrusive bodies in the central Alaska Range, Alaska: Fairbanks, Univ. Alaska unpub. M.S. thesis, 104 p.

Bultman, T.R, 1972, The Denali fault (Hines Creek strand) near the Nenana River, Alaska: Madison, Univ. Wisconsin unpub. M.S. thesis, $161 \mathrm{p}$.

Decker, J.E., and Gilberl, W.G., 1978, The Mount Galen Volcanic Formation in the central Alaska Range: Alaska Div. Geol. and Geophys. Surveys Geol. Repl. 59.11 D.

Gilbert, W.G., 1979, A geologic guide to Mount McKinley National Park: Alaska Natural History Assoc. in cooperation with the U.S. Natl. Park Service, $52 \mathrm{p}$.

Gilbert, W.G., Ferrel, V.M., and Tumer, D.L., 1976 , The Teklanika Formation-A new Paleocene volcanic formation in the central Alask a Range: Alaska Div. Geol. and Geophys. Surveys Geol. Rept. 47, 16 p.

Mankinen, E.A., and Dalrymple, G.B., 1972, Electron microprobe evaluation of terrestrial basalts for wholerock K-Ar dating: Earth and Planetary Sci. Letters, v. 17, no. 1, p. 89-94.

Turner, D.L., Forbes, R.B., and Naeser, C.W., 1973, Radiometric ages of Kodiak Seamount and Giacomin Guyot, Gulf of Alaska-Implications for CircumPacific lectonics: Science, v. 182 , no. 4112, p. 579 . 81 . 
Wahrhaftig, Clyde, 1970, Geologic map of the Healy D-4 Quadrangle, Alaska: U.S. Geol. Survey Geol. Quad. Map GQ-806.

Wahrhaftig, Clyde, Turner, D.L., Weber, F.R., and Srith, T.E., 1975, Nature and timing of movement on the Hines Creek strand of the Denali fault system, Alaska: Geology, v. 3, no. 8, p. $463-66$. 


\section{MULTIPLE GLACIATION IN THE BEAVER MOUNTAINS, WESTERN INTERIOR ALASKA}

By T.K. Bundtzen ${ }^{I}$

\section{INTRODUCTION}

The Beaver Mountains are a rugged, isolated, igneouscored massif in the Kuskokwim Mountains of southwestern Alaska, about $40 \mathrm{mi}$ southwest of McGrath, Alaska (fig. 1). Eakin (1913) and Mertie (1936) first recognized evidence of glaciation in the Beaver Mountains and nearby highlands such as the Sunshine Mountains and Cloudy Mountain. During a 1979 mineral resource investigation, the author found evidence of four Quaternary glaciations in the Beaver Mountains and adjacent lowlands. This study is based on 3-1/2 weeks of field work during August 1979 and 6 weeks of photogeologic interpretation of 1:40,000-scale black-andwhite aerial photographs.

\section{GEOGRAPHY}

The highest parts of the $400-\mathrm{mi}^{2}$ study area (fig. 2) have been carved and steepened by glacial erosion, but no glaejers exist today. Elevations in the Beaver Mountains range from $500 \mathrm{ft}$ in the valleys of Windy and Hunter Creeks to 4,150-ft-high unnamed peak about 2-1/2 mi southwest of Tolstoi Lake. Numerous peaks and ridges that rise above $3,000 \mathrm{ft}$ contrast with the lower, rounded hills of the nearby Kuskokwim Mountalns. The Beaver Mountains massif is an elongated noth-northwest-lrending ridgeline; major streams flow northeast and west southwest from this hydrographic divide through long, U.shaped valleys.

Vegetation on the lee (east-northeast) side of the divide below the average $2,500 \mathrm{ft}$ timberline consists of large stands of mature white spruce, alder, willow, and minor birch and a ground cover of shrubs and lichens. There are large areas of lichen-covered treeless tundra dominated by Cladonia west and north of the divide, where stands of trees are limited to protected valley bottoms.

The present climate combines the continental infiuence of interior Alaska and the cool maritime weather systems of Bristol Bay and the Bering Sea. Temperalures at McGrath range from $-64^{\circ} \mathrm{F}$ to $+89^{\circ} \mathrm{F}$, with a mean annual temperature of $25.5^{\circ} \mathrm{F}$. According to Fernald (1960, p. 201), mean annual precipitation at McGrath is 19.13 in., with 234 days of annual cloud cover;

\footnotetext{
${ }^{2}$ DGGS, College, AK 99708.
}

maximum precipitation occurs in August. Annual pre. cipitation in the Beaver Mountains is unknown but probably higher than at McGrath because of the rainshadow effect of the massif.

\section{SUMMARY OF BEDROCK GEOLOGY}

A generalized bedrock geologic map of the Beaver Mountains is shown on figure 1 . The oldest recognized rock unit consists of small discontinuous lenses of chert, limestone, and sandstone of Late Paleozoic age (Palc, fig. 1) in two outcrops protruding through glacial till 5 mi north-mortheast of Crater Mountain (Bundtzen and Laird, 1980). Lithic to sublithic shale, siltstone, sandstone, and conglomerate (Kkss) of the Kuskokwim Group (Cady and others, 1955) of mid- to Late Cretaceous age overlie the older rocks. Intruding and harn. felsing these layered rocks is the $60-\mathrm{mi}^{2}$ heterogeneous diorite-to-syenite Beaver Mountains Stock (Kdsm, fig. 2 ), which has yielded one $40_{\mathrm{K}} \cdot 40_{\mathrm{Ar}}$ mica crystalliza. tion age of $70.1 \pm 2.1$ m.y. (Bundtzen and Laird, 1980). A 1,600-ft-thick pile of basalt, andesite, crystal tuff, and minor tuffaceous sedimentary rocks (Kbc) overlies the Beaver Mountains Stock in the southern part of the study area. A major northeast-trending, high-angle fault Porms the northern topographic boundary of the Beaver Mountains.

The resistant intrusive and extrusive rocks in the Beaver Mountains are very similar to those in other glaciated highiands of southwestern Alaska such as Cloudy Mountail and the Taylor, Horn, and Russian Mountains (Patton and others, 1980; Cady and others, 1955).

\section{BEA VER CREEK GLACIATION²}

The oldest recognized glaciation in the study area is the Beaver Creek Glaciation, named for the extensive til] and glaciofluvial deposits on lower Beaver Creek, well beyond the limits of the Beaver Mountains ( $Q d$, Qdo, fig. 2). During this glaciation, ice occupied at least 78 cirques in the Beaver Mountains, extended down the Ganes, Beaver, Tolstoi, Billy Goat, and Windy Creek drainages, and scoured wide, U-shaped valleys.

\footnotetext{
Nomenclature for successive glaciations in this paper is in formal and used for comparative and descriptive conrenlence.
} 


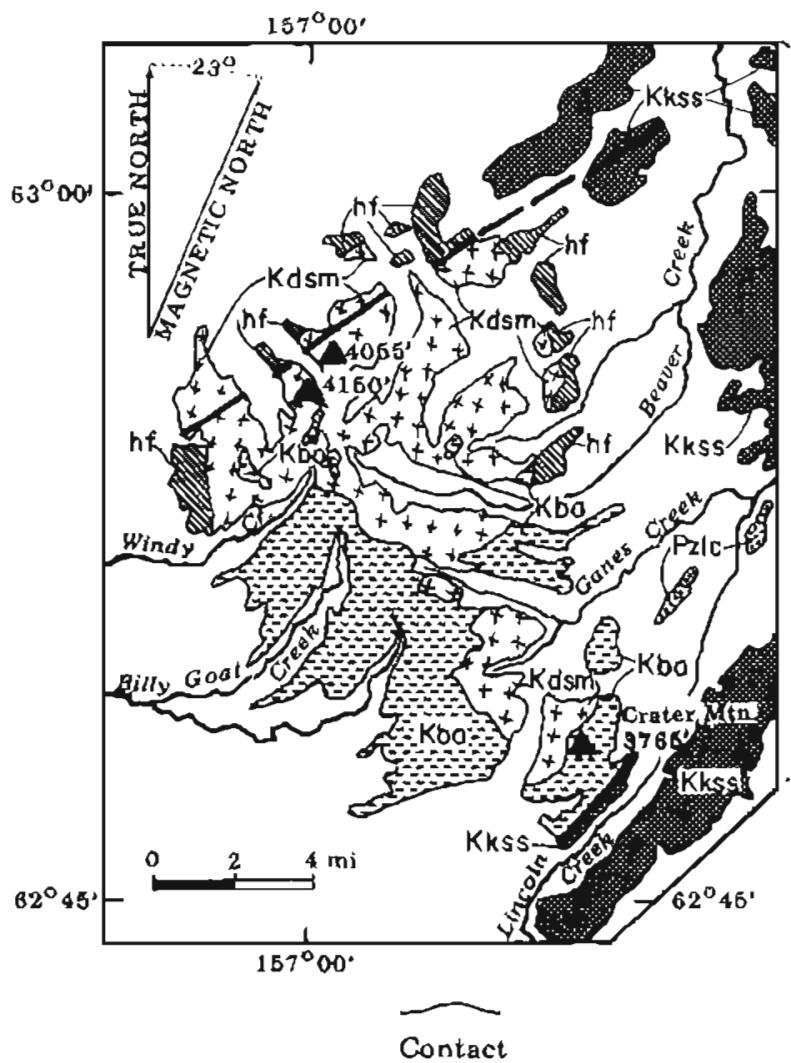

Contact

High-angle fault; dashed where inferred or covered

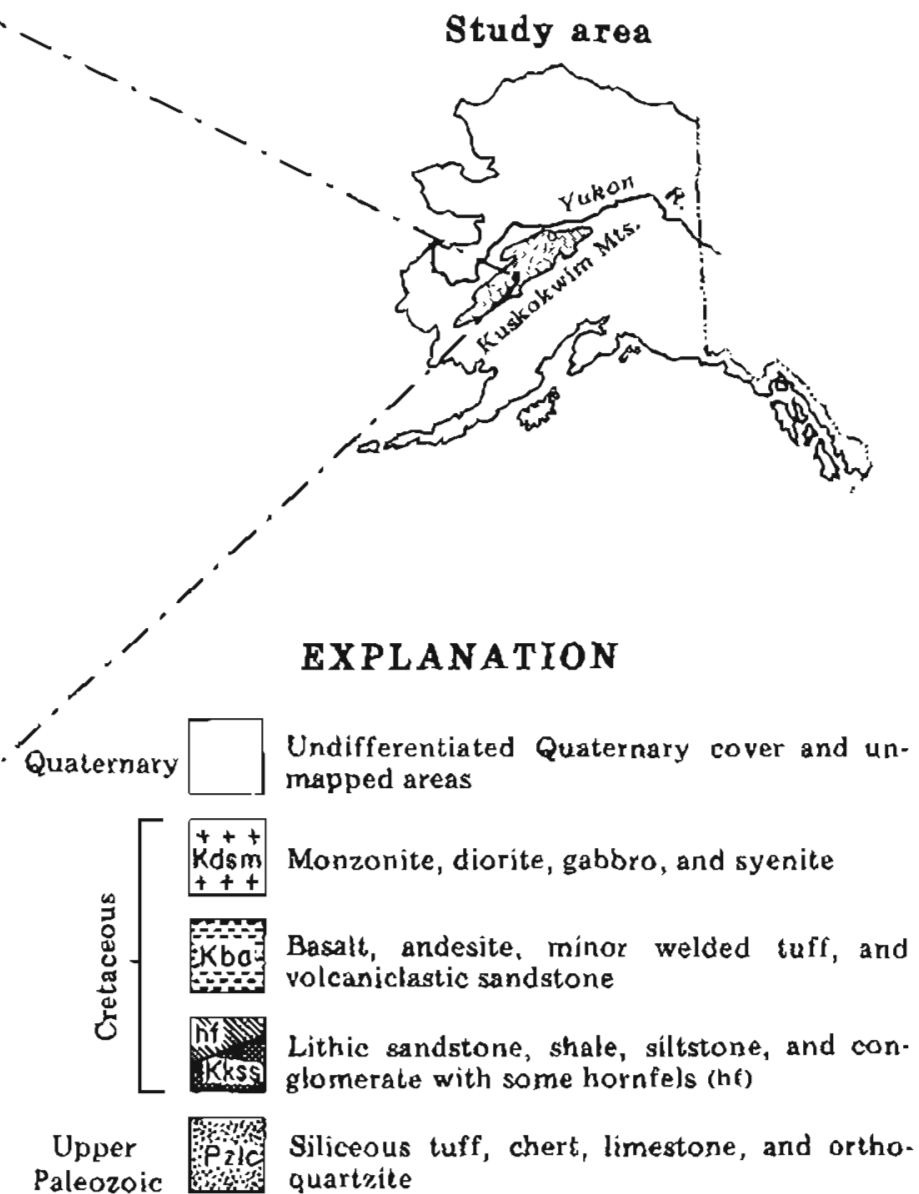

Figure 1. Location map showing generalized bedrock geology of Beaver Mountains, western interior Alaska.

Ice from several trunk glaciers coalesced on the outer flanks of the Beaver Mountains, as evidenced by the broad, till-covered, planated ridges at the 1,600 - $\mathrm{ft}$ elevation on the eastem, northern, and western limits of the upland. During the Beaver Creek maximum, ice in Ganes Creek overtopped the 2,960-ft divide with Beaver Creek, and a transfluent ice stream nowed into the Beaver Creelc drainage. Similarly, Beaver Creek ice breached the 2,700-ft-high divide on its north valley wall and allowed a diffluent ice stream to enter upper Brown Creek. Ice also breached lower divides between Tolstoi, Ganes, Last Chance, and Lincoln Creeks, which resulted in complex diffluent and transfluent ice flow that changed direction several times, depending on the relative vigor of the ice streams. During the Beaver Creek Glaciation, the central part of the massic was a $150-\mathrm{mi}^{2}$ ice sheet; only those peaks above $3,000 \mathrm{ft}$ protruded above the wide valley glaciers. Ice advanced down Tolstol and Beaver Creeks a minimum of 10 and $15 \mathrm{mi}$, respectively, and reached elevations as low as $900 \mathrm{ft}$.
Evidence for the Beaver Creek Glaciation consists of a) isolated patches of till ( $Q d$, fig. 2) on planated summits near the limits of the Beaver Mountains, b) faint breaks in slope as high as 3,000 it along valley walls that are befieved to represent ice limits in the Beaver Mountains and adjacent lowlands, c) distribution of ice. marginal meliwater channels far beyond the limits of younger glaciations, and d) drift (Qdo, fig. 2) in the Beaver, Hunter, and Windy Creek valleys. Mertie (1936) described till of probable Beaver Creek age at the confluence of Last Chance and Ganes Creek near Ganes Creek canyon (fig. 2) but the author did not visjt this locality. No terminal or lateral moraines are recognized.

Till and outwash deposits of Beaver Creek age are covered with a 3 . to 10 -ft-thick loess mantle. Numerous lakes and ponds in the Qdo deposits are probabiy thermokarst features developed in the ice-rlch perennially frozen eolian cover rather than youthful kettles. Breaks in slope denoting former ice limits high in the Beaver Mountains logically project downstream to the distribution of Qdo deposits (fig. 2). 
SHORT NOTES ON ALASKAN GEOLOGY $\cdot 1979-80$

Most cirque headwalts of Beaver Creek age have been rescoured by younger glaciations. The rest are ex. lensively modified by mass wasting, and coalescing talus cones and cirque floors are completely filted with rock rubble and alluvium. Slope angles of the cirques approach those of the surrounding valley walls and only a crude ice-scour morphology is retained. Small, northwest-oriented parabolic tributary valleys on the south side of Lincoln Creek may be cirques incised by later streams or they may be old nivation lnollows; in either case, their formation is correlated with the Beaver Creek Glaciation.

\section{BIFURCA'TION CREEK GLACIATION}

The Bifurcation Creek Glaciation is named after till in lower Bifurcation Creek valley. Ice advances were confined to wide, U-shaped valleys and downstream till limits extended to about $1,300 \mathrm{ft}$. Valley glaciers on the east-northeast side of the Beaver Mountains hydrographic divide averaged $6 \mathrm{mi}$ long, whereas glaciers nowing wesi-southwest averaged only $3-1 / 2$ to $4 \mathrm{mi}$ in length. During the Bifurcation Creek Glaciation, difIluent ice strcams crossed divides below the 2,600-it elevation between Ganes, Last Chance, and Lincoln Creeks, and between Tolsloi and Bifurcation Creeks. Sixty-eight of 78 cirques in the Beaver Mounlains were occupied by ice during the Bifurcation Creck Glaciation.

Two and sometimes three well-preserved terminal and recessional moralnes are present in almost all stream valleys. These are particularly well preserved in the Tolstoi and Bifurcation Creck valleys, where they have moderate to steep fronts $\left(10^{\circ}\right.$ to $\left.15^{\circ}\right)$, are not extensively dissected, and contain 10 to 30 small kettle lakes per mi ${ }^{2}$. Lateral limits 250 to $300 \mathrm{ft}$ above the modern streams are well defined along valley walls. Most Bifurcation Creek till deposits have well-developed soil profiles up to $18 \mathrm{in}$. thick, are covered with rounded igneous boulders $]$ to $6 \mathrm{fl}$ in diameter, and have been partially incised bv modern streams.

Cirque headwalls slope to $20^{\circ}$ and have been modified by talus cones and stream incision, but retain circular ice-scoured morphology. Clrque lloors are partially filled with rock rubble derived from these sources.

\section{TOLSTOI LAKE GLACIATION}

The Tolstoi Lake Glaciation, named after a 1.1-milong morainal-dam lake on the middle fork of Tolstoi Creek, is defined by several arcuate, steep-fronted terminal moraines in all major stream valleys that drain the Beaver Mountains and by lateral moraines about $150 \mathrm{ft}$ above main valley noors. Ice advanced $2-1 / 2$ to $4 \mathrm{mi}$ from cirque headwalls in Tolstoi, Ganes, and Bifurcation Creeks but only $1 / 2$ to $1 \mathrm{mi}$ in the remaining drainages. No divides were breached and ice was confined to valleys of origin. Most cirques on the northnortheast side of the mountains contained ice, but cirque glaciers developed only in those north-facing basins well protected on three sides ( 14 of 21 cirques) in the Windy-Billy Goat Crecks drainages.

Several morainal-dam lakes up to $3 / 4 \mathrm{mi}^{2}$ in area occur in north-facing valleys near the termini of maximum Tolstoi Lake advances. Tolstoi Lake till contains large, angular boulders of igneous rock up to $15 \mathrm{ft}$ long and bears a dense cover of Cladonia. Modern streams are usually diverted around till borders and only develop mature hydrologic gradients downstream from Tolstoi Lake moraines.

Cirque headwalls slope $30^{\circ}$ to $40^{\circ}$ and, except for a few talus cones, are largely unmodified. Cirque Ploors appear relacively unmodified and are composed of crude unsorted rock rubble and lichen-rich soil cover.

\section{CRATER MOUNTAIN GLACIATION}

The youngest recognized glaciation in the Beaver Mountains is named after a well developed cirque on the north side of Craler Mountain (fig. 2). Evidence of this advance is confined to cirques above $2,450 \mathrm{ft}$, particularly those on the east-norlheast side of the moun. tains. During the Crater Mountain Glaciation only 15 of 78 cirques in the Beaver Mountains contained lce; only one eirque southwest of the hydrologic divide shows evidence of ice containment. Sleep-fronted terminal moraines covered with rock rubble enclose larns 300 to $1,500 \mathrm{ft}$ in diameter. The $45^{\circ}$ to $70^{\circ}$ cirque headwalls are relatively unmodified, excepl for minor talus-cone development. A minimal soil profile and scaltered lichen cover are developed on Crater Mountain till.

\section{ROCK GLACIERS}

At least nine rock glaciers are present in the Beaver Mountains. These occur as lobate to spatulate masses of poorly sorted angular boulders and smaller rock fragments derived from cirque headwalls. Seven of the nine have rounded, subdued termini and soil propiles several inches thick; black lichens have developed on stabllized bedrock rubble. The seven rock glacicrs are located in northwest- or southwest-oriented cirque basins ranging from 2,000 to 2,500 $\mathrm{ft}$ in elevation. Norphology and distribution suggests these rock glaciers are inactive and probabiy related to the Tolstoi Lake or Crater Mountain Glaciations (Qr, fig. 2).

The two remaining rock glaciers in the Beaver Mountains ate probably active-one in a north-Pacing cirque on upper Ganes Creek at $2,620 \mathrm{ft}$ and the other on the northeast face of Mountain 3957 at 2,650 ft (Qr*, fig. 2). Both are lobate masses with fronts sloping more than $45^{\circ}$; dark lichen covers the upper surtaces. The unvegetated, light-toned, sloping inargins result from movement of angular basalt.andesite rubble. Clear water seeping from the terminus of the Ganes Creek rock glacier has filled a 5-acre pond near the cirque headwall; this water may be derived from melting interstitial ice. 


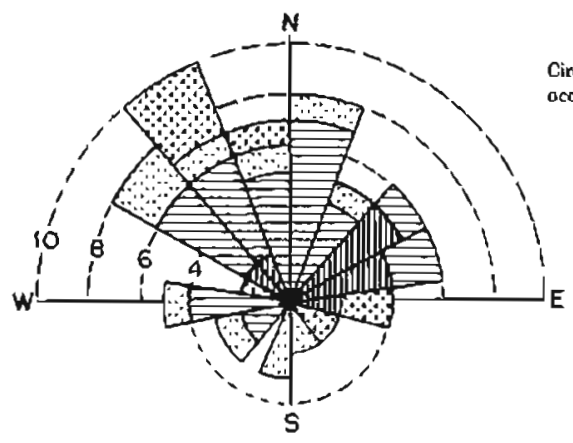

Crique orieotationa in study arex

Cirques of younger glaciations are assumed to have been accupied dunilg more axlensivo, older glaciations.

8. Beavor Craek Glaciation $(N-78)$

Bifurcation Crack Glaciation $(N=68)$

$\theta$ Tolstoi Lake Glaclation $(N-3 \theta)$

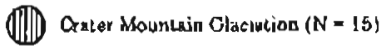

\section{Expanation}

Talus cone deposics

OQj:- Afluvial lan dopasica

Oof Outwreh Can deparits

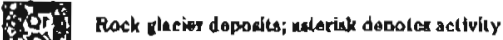

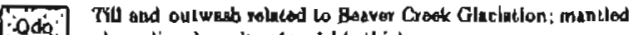

Tod Till of Beaver Creek ayo

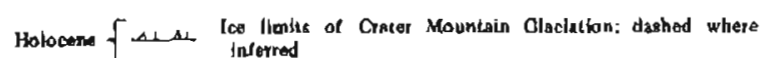

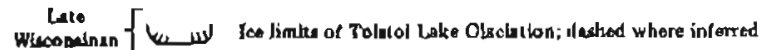

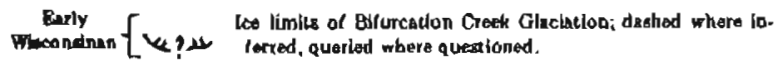

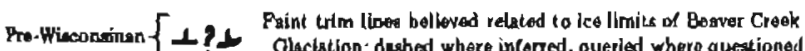

S? lce-marginal mell water chsobels of Barer Creek zge; queried

Lakes

- -... Cancuct, dached where inlerted

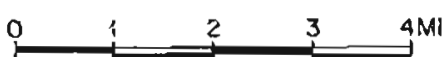

Figure 2. Map showing extent of late Quaternary glaciations in the Beaver Mountains, western interior Alaska.

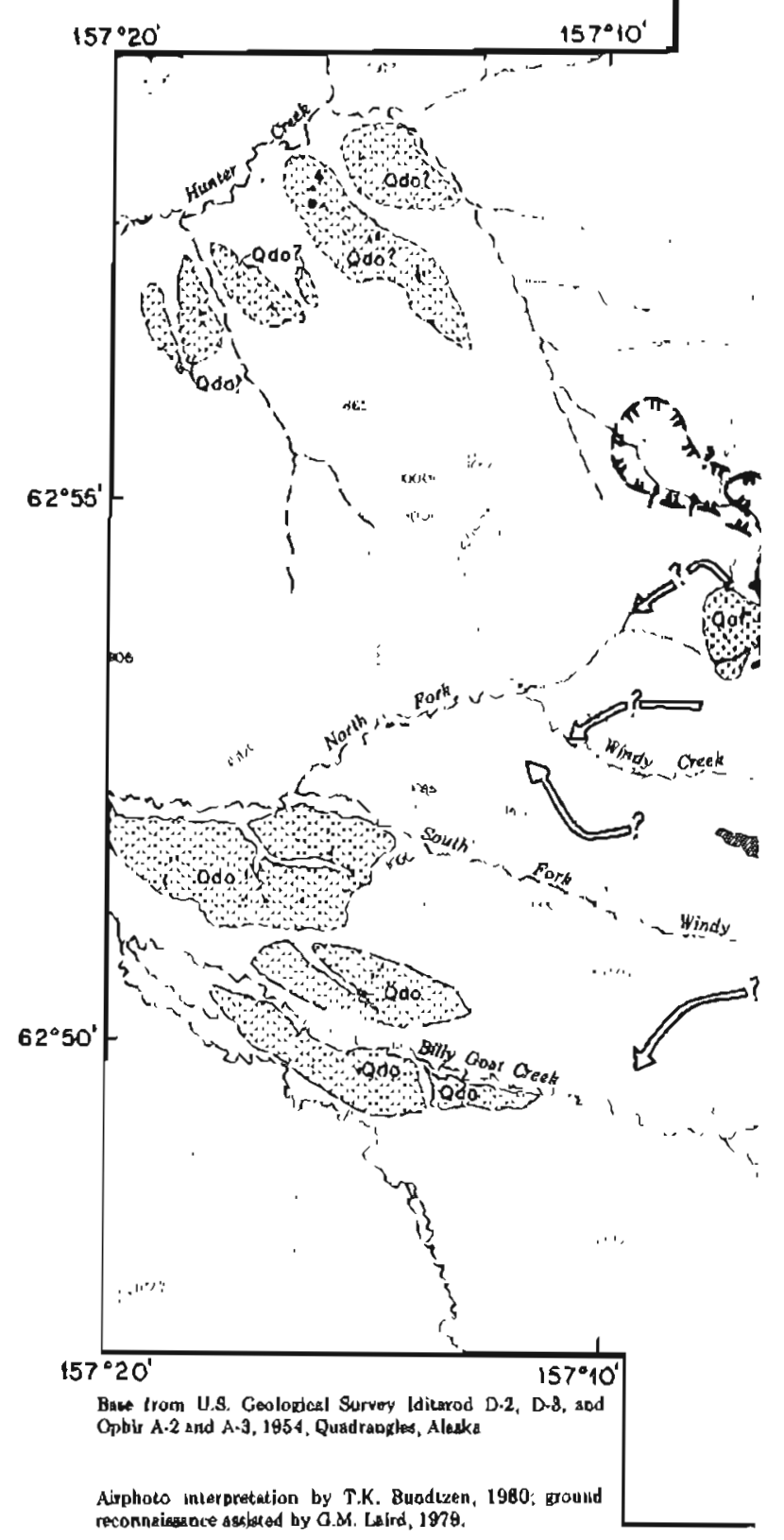




\section{AGE AND CORRELATION}

No radiometric or paleontological age control is available for glaciations in the study area, and reconstruction of a Beaver Mountains glacial chronology relies on relative-age-dating techıiques presented by Birkland and others (1979). Table 1 correlates glaciations of the Beaver Mountains with those described by other workers in selected regions of southwestern and western Alaska.

The absence of morainal landforms, the extensively modified character of till, outwash, and cirque headwalls, and the deep stream incision in valleys occupied by Beaver Creek ice are features similar to those of preSelatna (Fernald, 1960) and Clara Creek (Porter, 1967) Glaciations. Both are regarded as 1llinoian. 3 Characteristics of the Bifurcation Creek Glaciation include morainal landforms rounded by mass wasting and incised by stream erosion, soil profiles up to 18 in. thick, kettles filled with Sphagnum peat, and subangular to rounded till boulders with minor oxidation. These features are similar to those of the Selatna Glaciation ${ }^{3}$ near Farewell (Fernald, 1960), Porter's (1967) Chagvan Bay Glacialion, the Indian Mountain Glaciation near Hughes (Reger, 1978), and the Mak Hill Glaciation in the Iliamna Quadrangle (Detterman and Reed, 1973); all are regarded as early Wisconsinan.

Advances of the Tolstoi Lake Glaciation are believed to be late Wisconsinan lor several reasons: a) wellpreserved glacial landforms, b) poor development of soil cover, c) incomplete incision by modern streams, d) pre. sence of water-filled kettles and larger morainal-dam lakes, e) existence of large, angular till boulders, and f) minor modifications to cirque headwalls. The 'l'olstoi Lake advances are correlated with stades of the Farewell Glaciation (Fernald, 1960), the Brooks Lake Glaciation (Delterman and Reed, 1973), or the Unaluk Glaciation near Goodnews Bay (Porter, 1967).

The unmodified moraine morphology, lack ol mature soll development, presence of fresh, angular till boulders, and general absence of cirque headwall modification are characteristic of the Crater Mountain Glaciation. Similar features are described by Karlstrom (1964) and Detterman and Reed (1973) for the Alaskan Glaciation of post-Wisconsinan to Holocene age. Active(?) rock glaciers in two Beaver Mountains cirques suggest nearthreshold conditions for reinception of glaciation in the study area above $2,600 \mathrm{ft}$.

\footnotetext{
${ }^{3}$ Fcrnald (1960) concludes that the age of his Selatna Glaciation is problematical-either IIlinoian or carly IVisconsinan Ha regaxds the two Faxevell advances as late Wisconsinan. Pewe (1976) has shown the Selatna Glaciation as Illinoian on his statewide correlation chart and the lwo advances of Fare. well Glaciation as early and late Wisconsinan. However, d. $\Upsilon$. Kine (ord comm., 1980) believes the Sclalna Glaciatlon may be synchronous with the Delta Glaciation in the eastern Alaska Range. Cumulative evtdence suggests that the Della Glaciation is early Wisconsinan (R.D. Reger, aral comm.. 1980).
}

\section{CIRQUE ANALYSIS}

Orientation dala of cirques of the Beaver Creek, Bifurcation Creek, Tolstoi Lake, and Crater Mountain Glaciations (table 2, fig. 2) demonstrate that cirques of progressively younger glaciations assume a more north. erly orientation with dominant mean direction of each glaciation varying from $13^{\circ}$ to $37^{\circ}$. Statistical data on cirque orientations from the Bifurcation Creek and Beaver Creek Glaciations indicate polymodal distributions in the northwest, northeast, and southwest directions, whereas cirque orientations of the Tolstoi Lake and Crater Mountain advances show bimodal distributions to the northeast and northwest. Thus, the mean vectors for the different glaciations are the average of several distimct cirque orientations Prom each glaciation, as shown by the $R$ values and mean angular deviations (table 2). Cirque orientation data imply that orographic influences had less effecl during the older, more extensive glaciations than during the younger, more conlined ice advances. By Craler Mountain time, almost all active cirques werc confined to protected northerly basins.

Beaver Mountains cirque leveis range from 2,150 to 2,900 ft and average $2,495 \mathrm{ft}$ in elevation (fig. 2 , table 2), a level almost $1,500 \mathrm{ft}$ lower than cirques described in the Ruy Mountains (Yeend, 1971) and the Yukon-Tanana Upland (Pêwè, Burbank, and Mayo, 1967). Low cirque levels in the Beaver Mountains during Peistocene time call be attributed to higher precipitation rates or a cooler climate or hoth. Cady and others (1955) describe cirque basins of unknown age at elevations as low as 1,500 ft in the Taylor Mountains $150 \mathrm{mi}$ southwest of the Beaver Mountains.

\section{POSTGLACIAL READJUSTMENTS}

After lce receded Prom the Beaver Mountains, talus cones, outwash fans, and alluvial fans began to modify slope morphology. Subsequent to recession of Tolstoi Lake ice, small tributary streams deeply incised valley walss in Tolstoi and Bifurcation Creeks and deposited alluvial fans over valley hoor moraines. This process resulted in the division of the formerly 1-mi-long 'Bifurcation' Lake (Gig. 2). Talus cones modllied valley slopes and cirque headwalls subsequent to all major glaciations.

Deposition of till and outwash in several strearn drainages resulted in stream piracy and sharp drainage deflections. Mertie (1936) first described the stream capture of the headward reaches of the preglacial south cork of Beaver Creek by Ganes Creek. During the Besver Creek and Bifurcation Creek Glaciations, drift from upper Beaver Creek built up along the valley floor next to the low, rounded hills 10 mi east of the Beaver Mountains. Beaver Creek diverted around this material and incised a steep-walled canyon in the upper water- 
Table 1. Correlation chart of local Quaternary glacial sequences in the Beaver Mounlains and selected glacial chronologies in western and southweslern Alasha.

\begin{tabular}{|c|c|c|c|c|c|}
\hline $\begin{array}{l}\text { ABce of } \\
\text { placialions }\end{array}$ & $\begin{array}{l}\text { Furewell inga, } \\
\text { southern Alask an Rangu } \\
\text { (Feinald, 1960) }\end{array}$ & $\begin{array}{c}\text { Chithvan-Goodnews Bsy } \\
\text { area (Porter, 1967) }\end{array}$ & $\begin{array}{c}\text { lliamna Quadranigle } \\
\text { (Doilerman \& RLoud, } \\
\text { 1978) }\end{array}$ & $\begin{array}{l}\text { Beaver Mourtisins } \\
\text { (this study) }\end{array}$ & $\begin{array}{c}\text { Lislian Mounduin } \\
\text { (Reger, 1978) }\end{array}$ \\
\hline Holucene & & & $\begin{array}{l}\text { Alaskan Glacintion } \\
\text { (Tunnel Stade und } \\
\text { Tustumena Slado) }\end{array}$ & $\begin{array}{l}\text { Cracer Notultain } \\
\text { Glacialout } \\
\text { rocli ulaciars }\end{array}$ & \\
\hline Late Wisconsinan & $\begin{array}{l}\text { Fotlewell II Glocintion } \\
\text { Farewell I Claciation }\end{array}$ & Unaluk Glaciation & 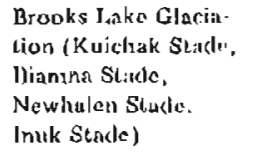 & $\begin{array}{l}\text { Tolatoi Lalce } \\
\text { Glaciation (3 } \\
\text { unnancd adi- } \\
\text { vinces) } \\
\text { rock glaciers }\end{array}$ & pock piaciers \\
\hline Early Wiscousinon & Selatna Glaciation & Chatuan Bay Glaciation & $\begin{array}{l}\text { Mak Hill Glaciation } \\
\text { (KukLklek SLadc) }\end{array}$ & $\begin{array}{l}\text { Bliucalion Creet. } \\
\text { Cjlocintlolt ( } 2 \text { in- } \\
\text { named advalices) }\end{array}$ & $\begin{array}{l}\text { Indinn Mountan } \\
\text { Glactation }\end{array}$ \\
\hline Illinoiun & flucialion(?) & Claru Creck Glacial ton & & 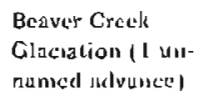 & $\begin{array}{l}\text { Slicpy Bear } \\
\text { Giaciacion }\end{array}$ \\
\hline Pw-Illinoiun & & Kemuk Glaciation & & & \\
\hline
\end{tabular}

Table 2. Summary of cirque measurements from Beaver Mounlains, Iditarod Quadrangle. (Orientation statislics after Reymenl, 1971)

\begin{tabular}{|c|c|c|c|c|c|}
\hline Glaciation & $\begin{array}{l}\text { Number of } \\
\text { cirques } \\
\text { measured } \\
(\mathrm{N})\end{array}$ & $\begin{array}{l}\text { Mean } \\
\text { orientation } \\
\text { vector }\left({ }^{\circ}\right)\end{array}$ & $\begin{array}{l}\text { Distance } \\
\text { from } \\
\text { origin } \\
(R \text { value })^{\mathrm{a}}\end{array}$ & $\begin{array}{l}\text { Mean angular } \\
\text { deviation }\left({ }^{\circ}\right)\end{array}$ & $\begin{array}{l}\text { Average } \\
\text { elevation }(\mathrm{ft})\end{array}$ \\
\hline $\begin{array}{l}\text { Crater } \\
\text { Mountain }\end{array}$ & 35 & 39 & 0.6444 & 48 & 2,650 \\
\hline $\begin{array}{l}\text { Tolstoi } \\
\text { Lake }\end{array}$ & 89 & 16 & 0.6212 & 49 & 2,583 \\
\hline $\begin{array}{l}\text { Bifurcation } \\
\text { Creek }\end{array}$ & 68 & 13 & 0.4193 & 61 & 2,516 \\
\hline $\begin{array}{r}\text { Beaver } \\
\text { Creek }\end{array}$ & 78 & $22^{b}$ & $0.3100^{\circ}$ & $68^{b}$ & $2,495^{b}$ \\
\hline \multicolumn{6}{|c|}{$\begin{array}{l}{ }^{a} R \text { value, or correlation coefficient, may vary from a value of } 1.000 \text { (unimodal population) to } 0.000 \text { (random popula- } \\
\text { tion). } \\
{ }_{\text {Average for all cirques in study area. }}\end{array}$} \\
\hline
\end{tabular}

shed of preglacial Ganes Creek to produce the present Ganes Creek valley. Drift from a Bifurcation Creek advance blocked the upper north fork of Lincoln Creek and caused the stream to divert along the north side of the moraine into Ganes Creek.

\section{ECONOMIC IMPLICATIONS}

Gold placers on lower Ganes Creek immediately east of the study area may have been derived from a localized bedrock source or from copper-silver-tourma. line-bearing vein faults that cut alkaline intrusive rocks of the Beaver Mountains Stock on Ganes and upper Bcaver Creeks (Bundtzen and Laird, 1980). If the mature auriferous bench and stream placers on Ganes Creek are derived from the latter, they must have formed since Beaver Creek time, inasmuch as Ganes Creek captured an upper lork of Beaver Creek after the Beaver Creek till and outwash were deposited.

It is more plausible that the auriferous benches on Ganes Creek formed before the Beaver Creek Glaciation and that their source is a structurally controlted, 
mineralized rhyolite-basalt dike swarm trending nortls. east through upper Ganes and Yankee Creek mapped by Bundtzen and Laird (1980).

\section{ACKNOWLEDGMENTS}

Invaluable assistance and thoughtful review by R.D. Reger, J.T. Kline, R.G. Updike, and C.L. Daniels (DGGS), and F.R. Weber (USGS) substantially improved the quality of this paper. G.M. Laird ably assisted the author during the August 1979 fjeld work, L.C. Schell performed the cartography. Bob Magnuson of Magnuson Airways flew the author and Laird into remote and difficult fixed-wing landing sites during the 1979 field studies.

\section{REFERENCES CITED}

Birkland, P.W., Colman, S.M., Burke, R.M., Shrolsa, R.R., and Meierding, T.C., 1979, Nomenclature of alpine glacial deposits, or, What's in a name?: Geology, v. 7 , no. 11 , p. $532-36$.

Bundtzen, T.K., and Laird, G.M, 1980, Preliminary geology of the McGralh-upper Innoko River area, western interior Alaska: Alaska Div. Geol and Gcophys. Surveys Open-lile Repl. 134, 36 p., 2 pl.

Cady, W.M., Wallace, R.E. Hoare, J.M., and Webber, E.J., 1955, The central Kuskokwim region, Alaska: U.S. Geol. Survey Prof. Paper 268, 132 p.

Detterman, R.L., and Reed, B.L., 1973, Surficial deposits of the Iliamna Quadrangle, Alaska: U.S. Geol. Survey Bull. 1368-A, p. 1.63.
Eakin, H.M., 1913, Gold placers of the Innoko-Iditarod region: U.S. Geol. Survey Bull. 642, p. 293-803.

Fernald, A.T., 1960, Geomorphology of the upper Kuskokwim region, Alaska: U.S. Geol. Survey Bull. 1071-G, p. 191-275.

Karlstrom, T.N.V., 1964, Quaternary geology of the Kenai Lowland and glacial history of the Cook Inlet region, Alaska: U.S. Geol. Survey Prof. Paper $443,69 \mathrm{p}$.

Mertie, J.B., 1936, Mineral deposits of the RubyKuskokwim region, Alaska: U.S. Geol. Survey Bull. 864.C, p. 115-24.7.

Patton, W.W., Jy., Mull, E.J., Dutro, J.T., Silberman, M.L., and Chapman, R.M., 1980, Preliminary geo. logic map of the Medfra Quadrangle, Alaska: U.S. Geol. Surv. Open-lile Rept. 80-811A.

Pewe, T.L., 1975, Quaternary geology of Alaska: U.S. Geol. Survey Prof. Paper 835, 146 p.

Pewe, T.L., Burbank, Lawrence, and Mayo, L.R., 1967, Multiple glaciation of the Yukon-Tanana Upland, Alaska: U.S. Geol. Survey Misc. Geol. Inv. Map I-507.

Porter, S.C., 1967, Glaciation of Chagvan Bay area, southwestern Alaska: Arctic, v. 20, no. 4, p. 227-46.

Reger, R.D., 1978, Glaciation of Indian Mountain, west-central Alaska: Alaska Div. Geol, and Geophys. Surveys Geol. Rept. 61, p. 15-18.

Reyment, R.A., 1971, [ntroduction to quantitative paleoecology: Elscvier Publishing Co., London and New York, p. 19-67.

Ycend, Warren, 1971, Glaciation of the Ray Mountains, central Alask a: U.S. Geol. Survey Prof. Paper 750-D, p. $122-26$. 


\title{
FOSSIL ALGAE IN LOWER DEVONIAN LIMESTONES, EAST-CENTRAL ALASKA
}

\author{
By James G. Clough 1
}

\section{INTRODUCTION}

Two genera of calcareous fossil algre, Girvanella and Renalcis, have been identified in thin sections of rocks from the Ogilvie Formation located in the Charley River Quadrangle, east-central Alaska and at one locality in the Yukon Territory (fig. 1). These cossil algae are important paleoenvironmental indicators of shallow-shelf lagoonal (Girvanella) and reef or bank-edge (Renalcis) deposition within a carbonate platform. Strata of the Ogilvie Formation were deposited during Early Devonian time on the southern part of the Yukon Stable Block (Lenz, 1972), an area of shallow-water carbonate scdimentation throughout much of the early Paleozoic.

\section{CHARACTERISTICS AND PALEONTOLOGY}

\section{GIRVANELLA}

Girvanella consists of tubular fllaments 7 to 30 microns in diameter entwined in loose irregular masses (fig. 2) and encrusting or perforating fossil fragments (Machielse, 1972). The filament walls are fine grained and dark in thin section. Differentiation of species within this genus is based on wall thickness and tube diameter. The Girvanella filaments shown in figure 2 have a tube diameter of 22.8 to 26.6 microns and a wall thickness of 5 to 7 microns.

The genus Girvanella, establislied by Nicholson and Etheridge (1880), is considered a blue-green (Schizo. phyta) alga referred to the family Porostromata on the basis of similar morphologic characteristics (Machielse, 1972).

It commonly occurs in a lagoonal back-reef setting (Wray, 1972) in limestones "representing a quiet, slightly restricted subtidal environment" (Machielse, 1972, p. 214). Girvanella has also been observed in voids between stromatoporoid skeletons in Devonian reefs (Konishi, 1958). It is found in rocks of Cambrian to Cretaceous age.

\section{RENALCIS}

Renalcis consists of chambered algae ranging in size from 30 to 300 microns in diameter that occur in grape-

\footnotetext{
${ }^{1}$ DGGS, College. AK 99708 and Geology and Geophysics Program, University of Alaska, Fairbanks, A K 99701.
}

like clusters (fig. 3) in a fan-shaped paitern (Machielse, 1972).

The genus lacks diagnostic characteristics readily related to living aigae, and Renalc is has been referred to the red algae (Rhodophyta) by Vologdin (1962) and to the blue-green algae (Schizophyta) by Johnson (1964) and Wray (1967), and is more recently considered a problematical blue-green algae (Machielse, 1972; Wray, 1977).

Renalcis commonly grew in "voids beneath laminar stromatoporoids, and separately in lime-mudstone intervals" (Cheshire and Keith, 1977, p. 30), where they often formed the core of Devonian reefs. Wray (1972) reports that their presence indicates deposition in reef and bank-edge environments. The genus is reported from Cambrian-through Devonian-age limestones.

\section{DISCUSSION}

Fossil Giroanella is present in some intervals of limestone from all three localities shown in figure 1 . At localities 1 and 2, Girvanello occurs in association with abundant crinoidal debris and less commonly with ostracod, brachiopod, and trilobite Pragments. At lo. cality 1 this alga occurs with the ostracod Mocllerila canadensis (identified by R.B. Blodgett, 1978), which has been described in restricted paleoenvironments within the Ogilvie Formation by Lenz (1972). At locality 3, Girvanella is found in interskeletal voids between colonial corals and stromatoporoids. This occurrence is similar to that reported by Konishi (1958), and suggests a shelf-margin biohermal paleoenvironment.

The fossil alga Renalcis is present in one interval of limestone from locality 2 , and a single intraclast con. taining this genus was observed in a sample of limestone from locality 3 . The genus occurs in a $1.8-\mathrm{m}$ interval of Renaicis lime-mudstone capped by the tabular stromatoporoid Trupetostroma (identified by R.B. Blodgett, 1978) at locality 2, indicating a biohermal environment (Cheshire and Keith, 1977). There, the limestones form a part of the $30 \cdot \mathrm{m}$-thick massive reef complex observed $0.6 \mathrm{~km}$ to the southwest by Blodgett (1978).

These genera of fossil algae are the westernmost recognized in upper Emsian strata of the region. Their presence and the associated biota that indicate a shelf-margin and shallow-shelf environment agree with the findings of Blodgett (1978) on the Ogilvie Forma. tion in this area. 


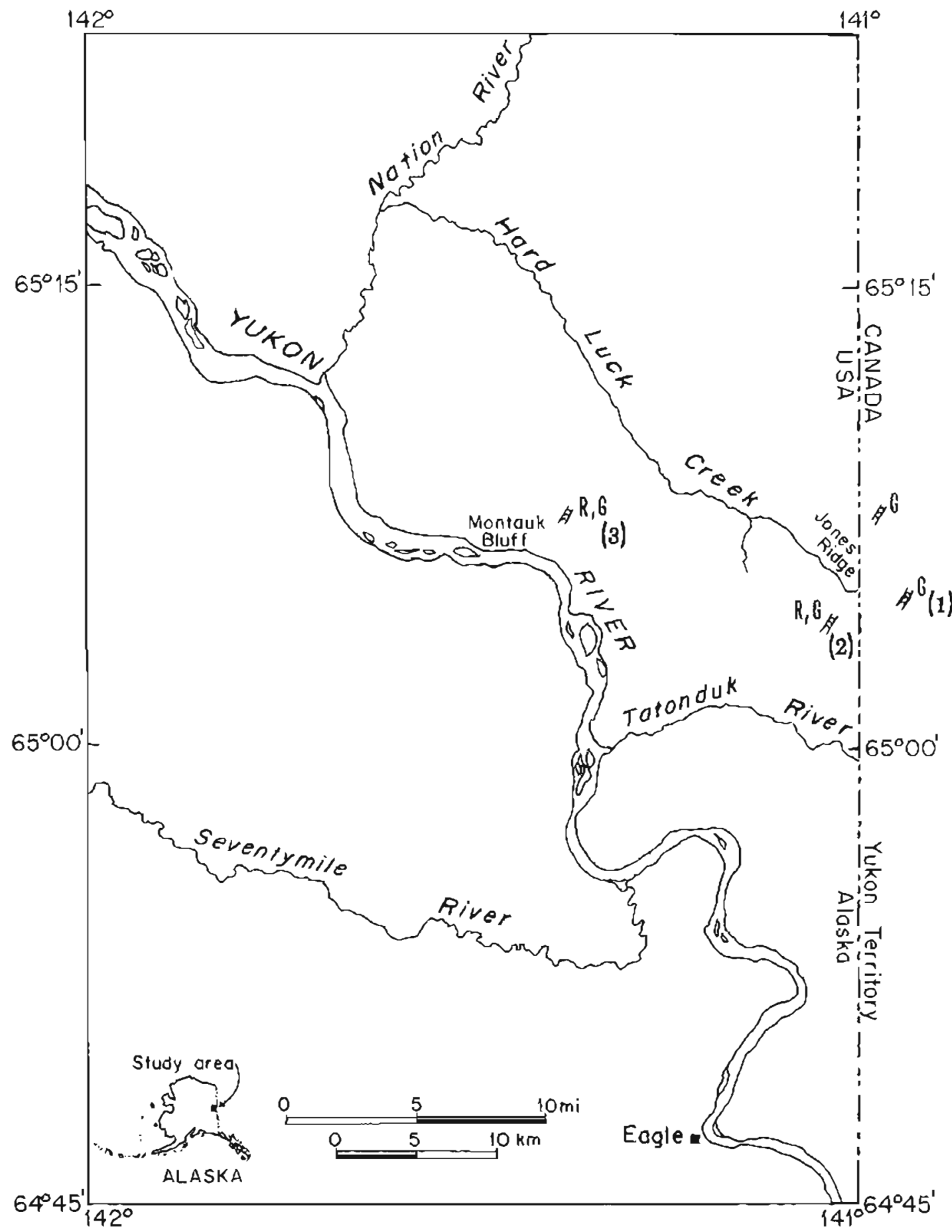

Figurc 1. Map showing microfossil localities in east-central Alaska ( $G$ - Girvanella, R-Renalcis). Locality I $-1.4 \mathrm{~km}$ east of International Boundary in Yukon Territory, Canads.

Locolity 2 - NE $1 / 4$ of NW 1/4 sec. 22, T. 3 N., R. 33 E, Charley River A.1 Quadrangle. Locality 3 - Center of sec. 34, T. 4 N., R. 31 E., Charley River A-1 Quadrangle. 


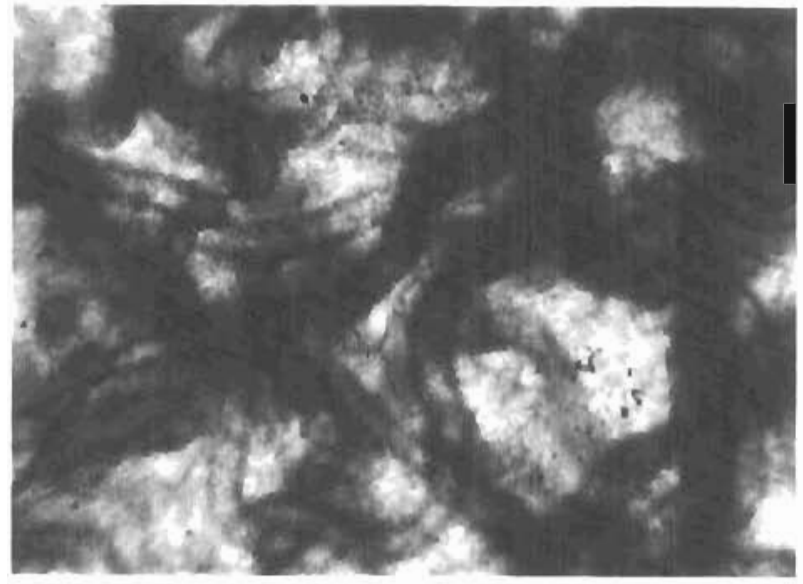

Fisure 2. Photomicrograph of entwined Girvanella filaments in micrite $(\mathrm{X} 160)$

\section{ACKNOWLEDGMENTS}

The author gratefully thanks C.W. Allison of the University of Alaska Museum and W.G. Gilbert of DGGS for reviewing the manuscript. The fossils shown in figures 2 and 3 are on deposit in the University of Alaska Museum, Fairbanks.

\section{REFERENCES CITED}

Blodget, R.B., 1978, Biostratigraphy of the Ogilvie Formation and limestone and shale member of the MeCann Hill Chert (Devonian), east-central Alaska and adjacent Yukon Territory: Fairbanks, Univ. of Alaska unpub. M.S. thesis, $142 \mathrm{p}$.

Cheshire, S.G., and Keith, J.W., 1977, Meekwap FieldA Nisku (Upper Devonian) shelf edge reservoir, in Supplemental to 1977 CSPG Core Conference manual: Canadian Soc. of Petroleum Geologists, 45 p. Johnson, J.H., 1964, Lower Devonian algae and encrusting Foraminifera from New South Wales: Jour. Paleontology, v. 38, no. 1, p. 98-108.

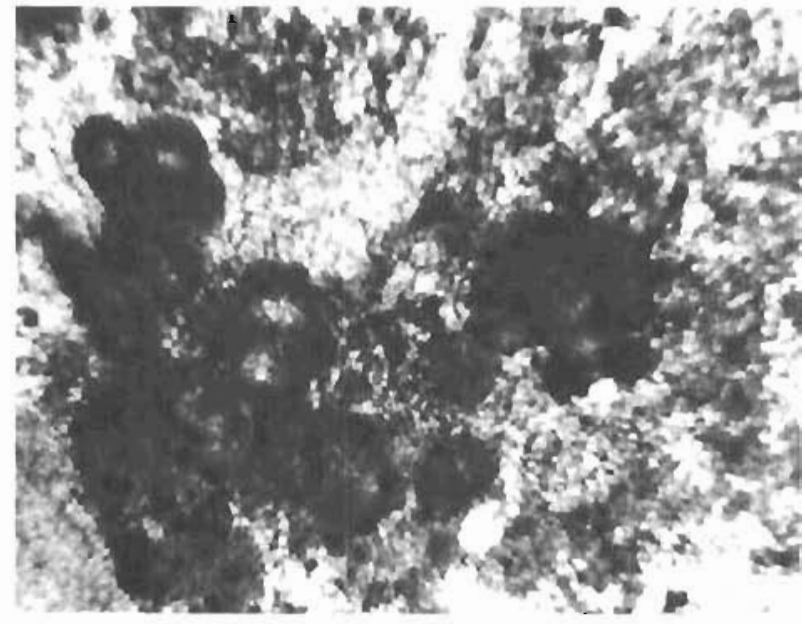

Figure 3. Photomicrograph of grapelike clusters of Renolcis: surrounded by micrite and microspar. Dark grains are hematite (X75).

Konishi, K.G., 1958, Devonian calcareous algae from Alberta, Canada: Colorado School Mines Quart., v. 53 , no. 2, p. $85 \cdot 109$.

Lenz, A.C., 1972, Ordovician to Deyonian history of Northern Yukon and ailjacent district of Mackenzie: Bull. Canadian Petroleum Geology, v. 20, no. 2, p. 321-61.

Machielse, S., 1972. Devonian algae and their contribution to the western Canadian sedimentary basin: Bull. Canadian Petroleum Geology, v. 20, no, 2, p. 187-237.

Nicholson, H.A., and Etheridge, R., 1880, A monograph of the Silurian fossils of the Girvan district of Ayrshire: Scotland Geol. Survey Mem., no. 23.

Vologdin, A.G., 1962, The most ancient algae of USSR: Akad. Nauk SSSR, 659 p. (in Russian).

Wray, J.L., 1967, Upper Devonian calcareous algae from the Canning Basin, western Australia: Colorado School Mines Prof. Contr., no. 3, 76 p.

1972, Environmental distribuitons of calcareous algae in Upper Devonian reef complexes: Geol. Rundschau, v. 61, p. 578-84. 1977. Calcareous algae: New York, Elsevier Scientific Publishing Co., 185 p. 



\title{
TERTIARY TILLITES(?) ON THE NORTHEAST FLANK OF GRANITE MOUNTAIN, CENTRAL ALASKA RANGE
}

\author{
By L. David Carter ${ }^{2}$
}

\section{INTRODUCTION}

Tilted beds of moderately consolidated pebble, cob. ble, and boulder conglomerate compose three ridges west of the Gerstle River on the northeast flank of Granite Mountain, central Alaska Range (figs. 1 and 2a). These strata are especially interesting because some of the beds contain boulders as large as $2 \mathrm{~m}$ in diameter and may be Tertiary glacial deposits, and some boulders are of lithologies not present in modern drainage basins adjacent to the ridges. Knowledge of the depositional and postdepositional history of these strata is important to understanding a) the fault movement along the northeast side of Granite Mountain, b) the uplift of Granile Mountain and the Alaska Range, c) regional -drainage development, and d) the age of inilial late Cenozoic alpine glackation in the Alaska Range.

The conglomernte beds were first noted by Moffit (1942, 1954), who correlated them with the Nenana Gravel, but he did not mention the presence of large houlders. Other deposits in the vicinity that have been correlated with the Nenana Gravel are on Independent Ridge (Holmes and Foster, 1968), at the northermmost corner of Granite Mountain (Holmes and Pewe, 1965), and southwest of Granite Mountain near McCumber and Jarvis Creeks (Moffit, 1942, 1954). The term 'Nenana Gravel' was first applied by Capps (1912) to a series of beds that is exposed along part of the Nenana River and that is widespread on the north flank of the Alaska Range. These beds are generally considered to predate glaciation in the Alaska Range and to have been deposited by streams rejuvenated during initial uplift of the range (Capps, 1940). The most recent estimate of the age of the Nenana Gravel is late Miocene and early Priocene (Wolfe and Tanai, 1980, p. 9).

\section{DESCRIPTION}

The conglomerate ridges extend about $2 \mathrm{~km}$ north from the steep margin of Granite Mountain. The maximum elevation on the ridge crests is about $880 \mathrm{~m}$, whereas elevations of as much as $1,800 \mathrm{~m}$ occur on the gently rolling but deeply dissected erosion surface at the top of Granite Mountain. The contact between the

\footnotetext{
${ }^{1}$ U.S. Geological Survey, 345 Middlefield Poad, Menlo Park, CA 94026 .
}

tilted beds and the quartz and quartz-mica schist that make up this part of Granite Mountain is not exposed. However, an extensive crushed zone occurs near the base of the range-front scarp about $9 \mathrm{~km}$ to the nortliwest, and the contact between the sedimentary beds and the schist is inferred to be a fault (fig. 1).

Bedding in the conglomerate is emphasized by differential erosion. Beds ricliest in boulders are more resistant than adjacent strata and stand in relief on the flanks and erests of the ridges (fig. 2). The beds strike northwest, parallel to the range front, and dip northeast at $40^{\circ}$ to $60^{\circ}$. In general, the beds could not be traced from ridge to ridge and the presence of unconformities or faults within the scction could not be determined. However, one massive bouldery bed that occurs at about the middle of the section is traceable across all three ridges and apparently thins to the northwest.

Megsurement of the strata of the central ridge demonstrated that the total thickness exceeds $1,000 \mathrm{~m}$ (fig. 3). In the lower $325 \mathrm{~m}$ of the section only one boulder-bearing bed occurs. It is $20 \mathrm{~m}$ thick and occurs $145 \mathrm{~m}$ above the base of the section. Boulders are present in the upper $675 \mathrm{~m}$ of the section except in two zones: a) a $60-\mathrm{m}$-thick zone that is $580 \mathrm{~m}$ above the base of the section and b) a 90 -m-thick zone $710 \mathrm{~m}$ above the base. None of the beds are well exposed and sedimentary structures, aside from the gross differentiation of beds due to differentlal erosion, were not observed.

Boulder-fire beds consist of pebble to cobble conglomerate. Clasts are predominantly hard, fine-grained siliceous rocks, including quartzite, quartz, chert, and chert conglomerate, but volcanic and metamorphic rocks and felsic to mafic intrusive rocks are also present. Clasts are well rounded and generally have orangecolored iron oxide coatings. Weathering rinds are as thick as 2 to $3 \mathrm{~mm}$.

In boulder-bearing beds, clasts are as much as $2 \mathrm{~m}$ in longest dimension, and a length of $1 \mathrm{~m}$ is common (fig. 2b). The largest boulders are generally concentrated in units from 10 to $20 \mathrm{~m}$ thick, except for one massive 140-m-thick zone in the center of the section in which boulders are especially abundant. Boulder shapes range from angular to rounded; subrounded clasts are most common. Boulder lithologies include schist, quartz, felsic to mafic intrusive rocks, gneiss, and a distinctive porphyritic granitic mck in which phenocrysts are as 


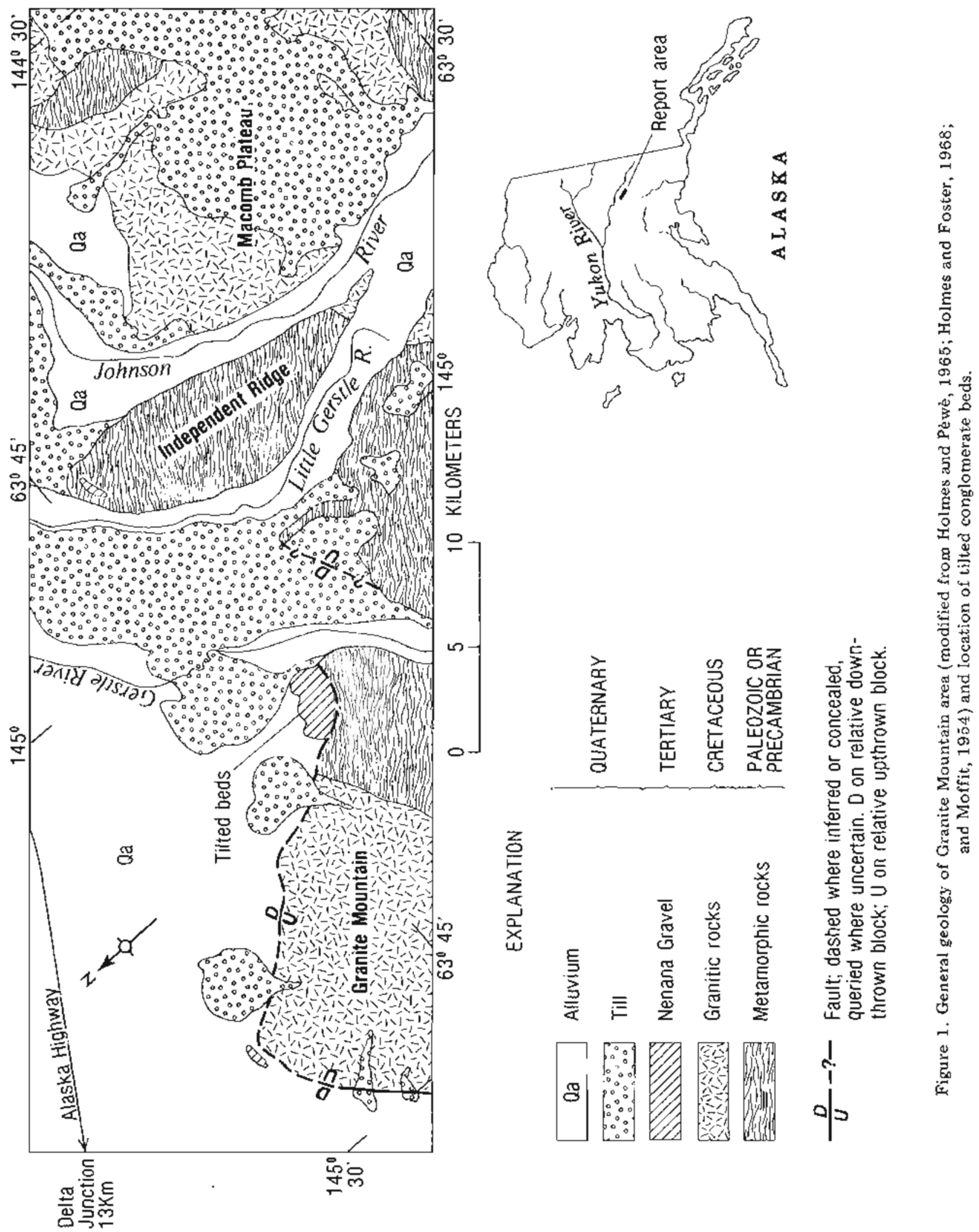




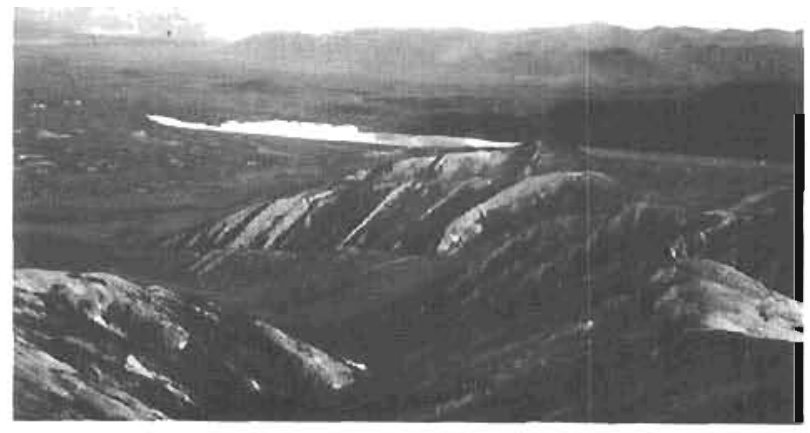

Figure 2a. View toward east from Granife Mounlain showing tilted beds in center, Gerste Risw bevond. and Independent Ridge in background.

long as $3 \mathrm{~cm}$. Rounded pebules and cobbles like chose described for the boulder-free beds constitute much of the pebble- to cobble-size malerial in the luwer two. thirds of the section; in the upper one-third these clasts are less common, and angular to subieunded clists of quariz schist and mica schist are abundant. 'The sabdy' matrix conlains abundant angular grains.

The state of weathering of the boulders runges from relatively fresh clasts that are difficult to break with a hammer to thoroughly rotted ones that disintegrate easily under a few hammer blows. Boulders on the sur. Cace appear relatively fresh. whereas those recently cxposed in a soil failure are highly weathered, and some of the granites are grusified. Apparently, boulders in the soil zone al this locality weather more rapidly than those on the surface, perhaps because of prolonged contact with soil moisture. Striations were not observed on clasls of any size. However, no original surfaces may remain.

\section{SIGNIFICANCE}

I agree with Morfit (1942) in correlatings the boulderfree beds with the Nonuma Gravel and agree that they were deposited under nonglacial, fluvial conditions. However, the prestince of large boulders in the rest of the beds implies either a powerlul transporting mechanism (glaciers, debris flows, torential streams) or a nearby source teyrane of high relie $[$, or both. The variety of boulder lithologies suggests either long-dislance trans. port or a nearby heterogeneous source terrane. Most of Whe rock types composing the boulders occur as dikes and small intrusive bodies in the metanorphic terrane south of the ridges, but a notable exception is the porphyritic gramitic rock. The nearesi exposures of granitic rocks are $5 \mathrm{~km}$ northwest on Granite Mountain and $16 \mathrm{~km}$ southeast on Independent Ridge and Macomb Plateau (fig. 1). The only grinitic pluton known to occur in the Gerstle River drainage is about $25 \mathrm{~km}$

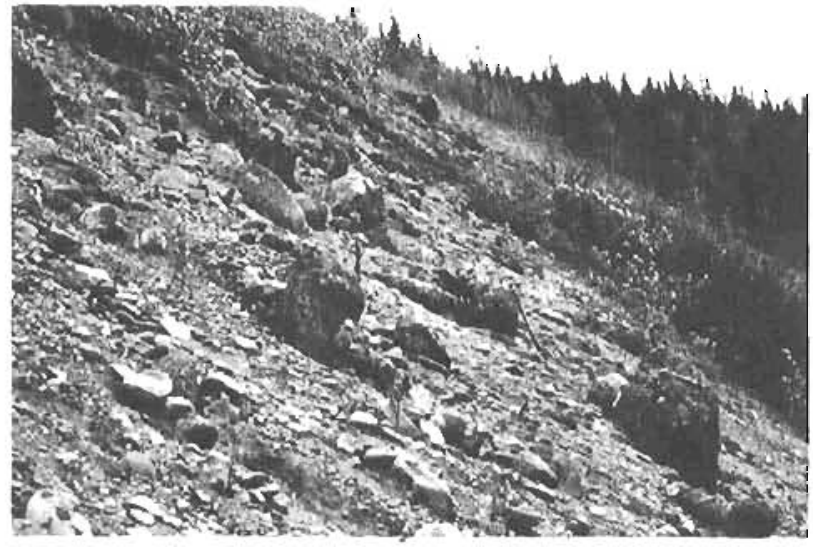

Figure 2b. Boulders exposed on slope of central ridge. Shovel near center of photograph is atsou $1 \mathrm{~m}$ long.

upstream from the valley mouth. Porphyritic granite is present in parts of the pluton, but the maximum phenocrysi. size observed is aboul $1.2 \mathrm{~cm}$, and this pluton is therefore not befieved to be the source of the porphyritic granitic rock in the tilturl beds. The prob. lem of the source ol these granitic boulders is intimately related to the mode of deposition, relation to fanlting. and regional drainage development. Unfortunately, the source cannot be determined with the dala at hand, but speculations serve to emphasize tine importance of the tilled beds to an understanding of regional geologic history.

Ir Granite Mountain were the source of the granitic boulders and if the beds were deposited during uplift of the range and initiation of the present drainage system, the boulder-bearing beds must have been deposited al the mouth of a valley that is $5 \mathrm{~km}$ northwest of the ridges, because this is the only valley draining the norlinast side of Granite Mountain in which both granilic and metamorphic rocks are exposed. If this valley were the source of the granitic clasts, $5 \mathrm{~km}$ of right-lateral movement must have occurred along a fault at the northeast margin of the range aliter deposition of at Iest $1,000 \mathrm{~m}$ of gravel to produce the present separation between the deposits and their source. How. ever, movement along the Granite Mountain tauit, which occurs along the northwest side of Granite Mountian, has been dominantly normal (Holmes and Pewe, 1965; Hudson and Wober, 1977). The fault along the northeastem edge of the range is presumably part of the same fault system, and $5 \mathrm{~km}$ of right-slip is considered here to be improbable because of the style of normal ofisel.

Derivalion of the boulders from Granite Mountain before uplift of the range is also not consideriod likely. The subdued erosion surface on Granile Mountain indicates that this was an area of low relief before uplift of the range, and if the boulders had been transporled actoss this surface from the northwest, residual 


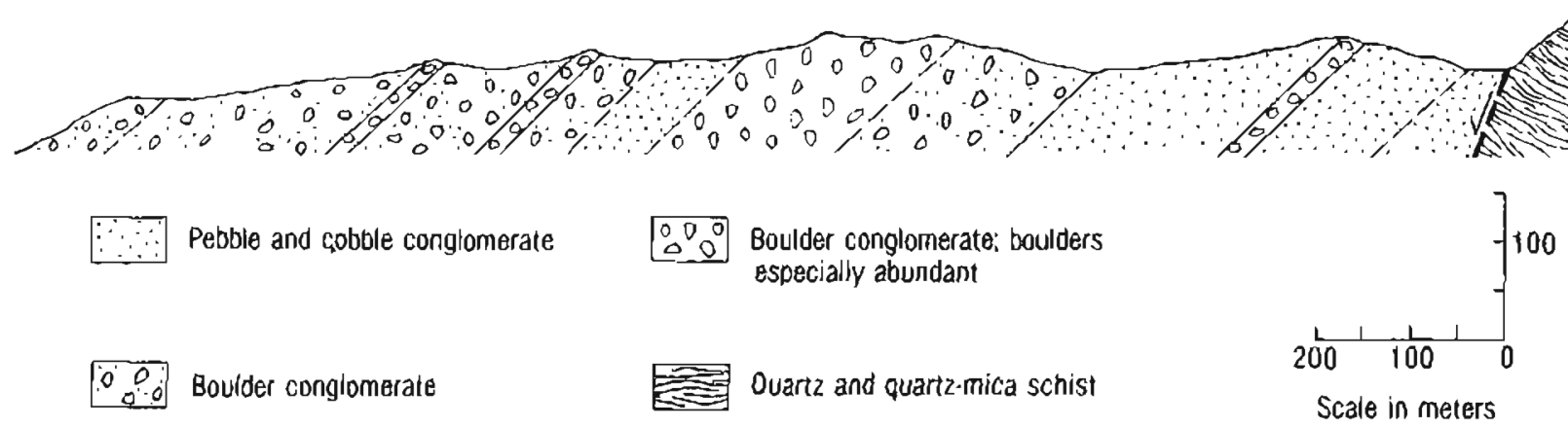

Linlerred lault: arrow indicates relative movement
- Contact: dashed where inferred

Figure 3. Longitudinal section through central ridge.

boulders should occur on this ancient surface adjacent to the tilted beds. However, neither the Nenana Gravel nor granitic boulders have been observed there.

A more likely hypothesis is that the source for the porphyritic granitic boulders was to the southeast. near Independent Ridge and Macomb Plateau (fig. 1). This hypothesis requires deposition of the boulderbearing beds before development of the modern drainage system. The minimum distance of $16 \mathrm{~km}$ between the 2-m-diameter boulders and their potential source argues against either torrential streams or deirris nows as the mechanism of transport, unless an extremely high range-front scarp was present in the granitic terrane. Therefore, ice most likely played a role in the emplace. ment of the boulders, either in the form of ice rafting or glacial ice.

Ancient glaciations previously recognized in the Alaska Range (Pèwè and others, 1953; Wahrhaftig, 1958) were considered to be younger than the Nenana Gravel and are probably Pleistocene, but Tertiary glacial deposits have been identified elsewhere in Alaska (Plafker and Addicott, 1976; Hamilton, 1979). If the boulder-bearing beds are tills, the Nenana Gravel includes glacial deposits at this locality and the tilted strata may record the inception of late(?) Tertiary glaciation in the Alaska Range and document a change from generally nonglacial conditions to a glaciated Alaska Range.

\section{ACKNOWLEDGMENTS}

I thank R.D. Reger, F.R. Weber, M.P. Springer, and J.P. Galloway for lively and helpful discussions in the Field. Constructive criticism of the manuscript was provided by O.J. Ferrians, Jr., T.D. Hamilton, and Reger.

\section{REFERENCES CITED}

Capps, S.R., 1912, The Bonnifield region, Alaska: U.S. Geol. Survey Bull. 601, 64 p. 1940, Geology of the Alaska Rail. road region: U.S. Geol. Survey Bułl. 907, 201 p.

Hamilion, T.D., 1979, Late Cenozoic glaciations and erosion intervals, north-central Brooks Range, in Johnson, K.M., and Williams, J.R., eds., The United Stales Geological Survey in Alaska: Accomplishments during 1978: U.S. Geol. Survey Circ. 804-B, p. B27B29.

Holmes, G.W., and Foster, H.L., 1968, Geology of the Johnson River area, Alaska: U.S. Geol. Survey Bull. $1249,49 \mathrm{p}$.

Holmes, G.W., and Pewe, T.L., 1965, Geologic map of the Mt. Hayes D-3 Quadrangle, Alaska: U.S. Geol. Survey Geol. Quad. Map GQ-366.

Hudson, Travis, and Weber, F.R., 1977, The Donnelly Dome and Granite Mountain faults, south-central Alaska, in Blean, K.M., ed., The United States Geological Survey in Alaska: Accomplishments during 1976: U.S. Geol. Survey Circ. 751-B, p. B64-B66.

Moffil, F.H,, 1942, Geology of the Gerstle River District, Alaska, with a report on the Black Rapids Glacier: U.S. Geol. Survey Bull. 926-B, p. 107-60.

, 1954, Geology of the eastern part of tho Alaska Range and adjacent area: U.S. Geol. Survey Bull. 989-D, 218 p.

Pewe, T.L., and others, 1953, Multiple glaciation in Alaska, a progress report: U.S. Geol. Survey Circ. 289, $13 \mathrm{p}$.

Plafker, George, and Addicott, W.O., 1976, Glaciomarine deposits of Miocene through Holocene age in the Yakataga Formation along the Gulf of Alaska margin, Alaska, in Miller, T.P., ed., Recent and ancient sedimentary environments in Alaska: Alastea' Geol. Soc. Symposium, Anchorage, 1975, Proceedings, p. Q1-Q23. 
Wahrhaftig, Clyde, 1958, Quaternary geology of the Nenana River valley and adjacent parts of the Alaska Range, in Wahrhaftig, Clyde, and Black, R.F., 1958, Qualemary and engineering geology in the central part of the Alaska Range: U.S. Geol. Survey Prof. Paper 293-A, p. 1-78.

Wolfe, J.A., and Tanai, Toshimasa, 1980, The Miocene Seldovia Point flora from the Kenai Group, Alaska: U.S. Geol. Prof. Paper 1 105, p. 1-52. 



\title{
EVIDENCE FOR SUPRAPERMAFROST GROUND-WATER BLOCKAGE, PRUDHOE BAY OIL FIELD, ALASKA
}

\author{
By Gail D. March ${ }^{1}$
}

\section{INTRODUCTION}

Permafrost in gravel pads and roads at the Prudhoe Bay oil field blocks the llow of ground water. The resultant dammed water forms ponds, creating a potential threat to the facilities.

\section{PHYSIOGRAPHIC DESCRIPTION}

The Prudhos Bay oil field is located on the Arctic Coastal Plain of Alaska (fig. 1), a physiographic province characterized by a low-relief lundra landscape cut by rivers flowing from the Brooks Range north to the Beaufort Sea. The tundra surface is underlain by complex ice-rich sediments of Pleistocene age (Sellman and others, 1975). Lakes and drained lake basins make up from less than 25 percent to more than 90 percent of the tundra surface (Brewer, 1958a). Much of the tundra surface is characterized by high-and low-center polygons ranging from 2 to $30 \mathrm{~m}$ in diameter (Pewe, 1966).

\section{AIRPHOTO COMPARISONS}

Black-and-white aerial photographs (scale 1:18,000) of the Prudhoe Bay area taken July 20, 1949 were examined to determine the extent of lakes and llooded polygons. A representative sample of the area covered is shown in figure 2. The discovery well at Prudhoe Bay was completed in 1968 (Morgridge and Smith, 1972). Within the next 5 years, two airstrips, more than 25 gravel pads for wells and support facilities, and many miles of connecting roads were built. A photomasaic (scale 1:24,000) taken in July 1973 was examined for changes in the extent of lakes and hooded polygons since 1949. The low quality of the mosaic made precise spatial determinations difficult, but it was possible to see that some formerly drained lake basins next to gravel pads and roads had flooded since 1949.

By July 1979, more than 30 gravel pads existed in the eastern half of the area alone, and there was a corresponding increase in connecting roads. Color airphotos (scale 1:18,000) taken July 13, 1979 were examined for further evidence of refilled lake beds and nooded polygons. Figure 3 shows the extent of ponded water in the same representative area as figure 2.

\footnotetext{
$1_{\text {DGGS. College, AK } 99708}$
}

A comparison of figures 2 and 3 shows that in 30 years, many changes accurred in the area which now contains the main support facilities for production welis in the Prudhoe Bay oil cield. A former lake basin next to the road southwest of Lake Colleen has refilled and polygons near the road south and east of the lake have flooded. An extensive area of ponded water has formed west of the Sagavanirktok River, surrounding numerous gravel pads. Smaller areas of llooded polygons in the vicinity of gravel pads and roads are also visible in figure 3 .

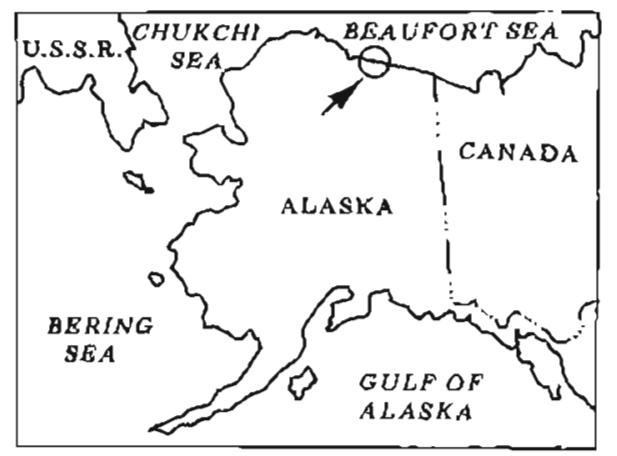

Figure 1. Location of Prudhoe Bay oil field, Alaska.

\section{DISCUSSION}

Refilled lake basins and greatly increased areas of fooded polygons appear to have a direct cortelation with the gresence of gravel fill. A hypothesis that ponded water next to the fill could be a result of drifted snow or blown dust was rejected. Benson and others (1975) state that storm winds responsible for drifted snow are from the west, causing snow accumulation on the east side of gravel roads, and that summer dust is transported by prevailing northeasterly winds, causing deposition on the west side. Ponded water appears to bear no relation to storm or prevailing winds. Instead, its orientation with respect to gravel fill appears to depend on topography, with water ponding on the up. slope side of the fill.

In the Prudhoe Bay area, gravel fill $1.5 \mathrm{~m}$ thick is used for roads dynamically loaded by vehicles, whereas fill $1 \mathrm{~m}$ thick is used on statically loaded well and support facility pads to prevent thaw of undertying perma- 


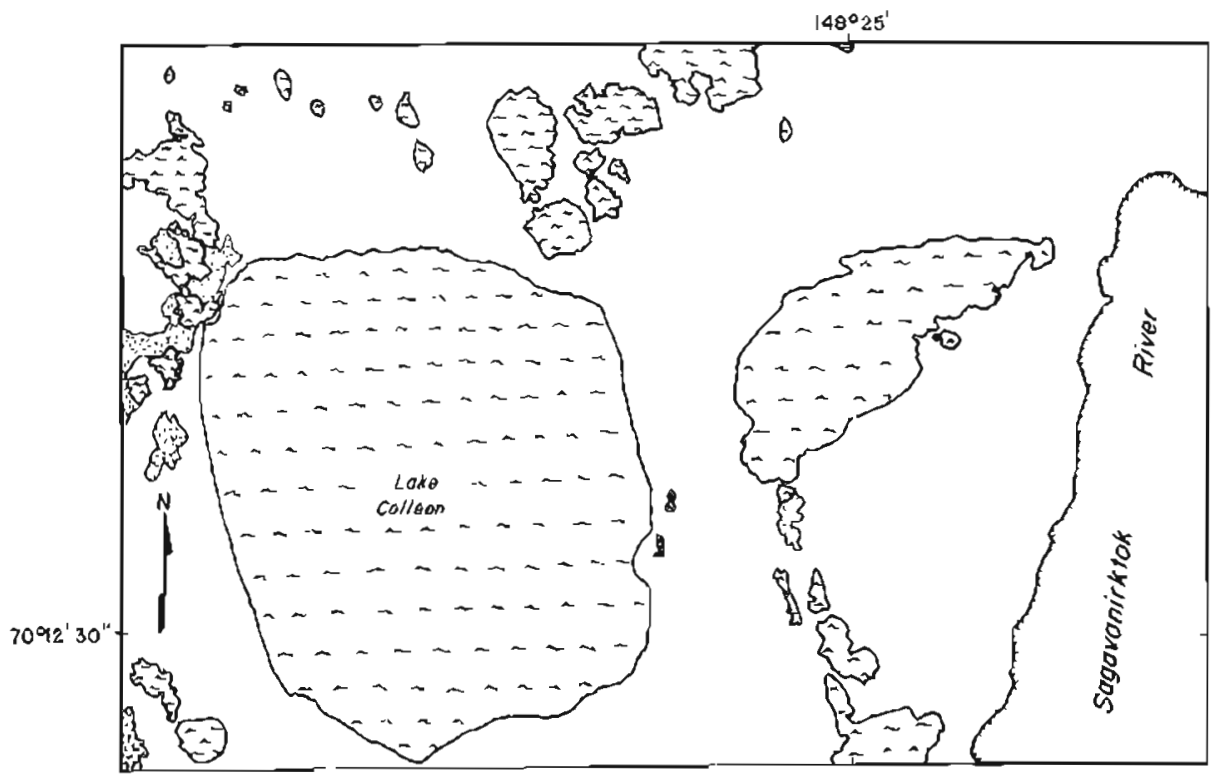

Figure 2. Extent of inundated polygons in part of Prudhoe Bay oil ficld, Alaska, July 20, 1949.

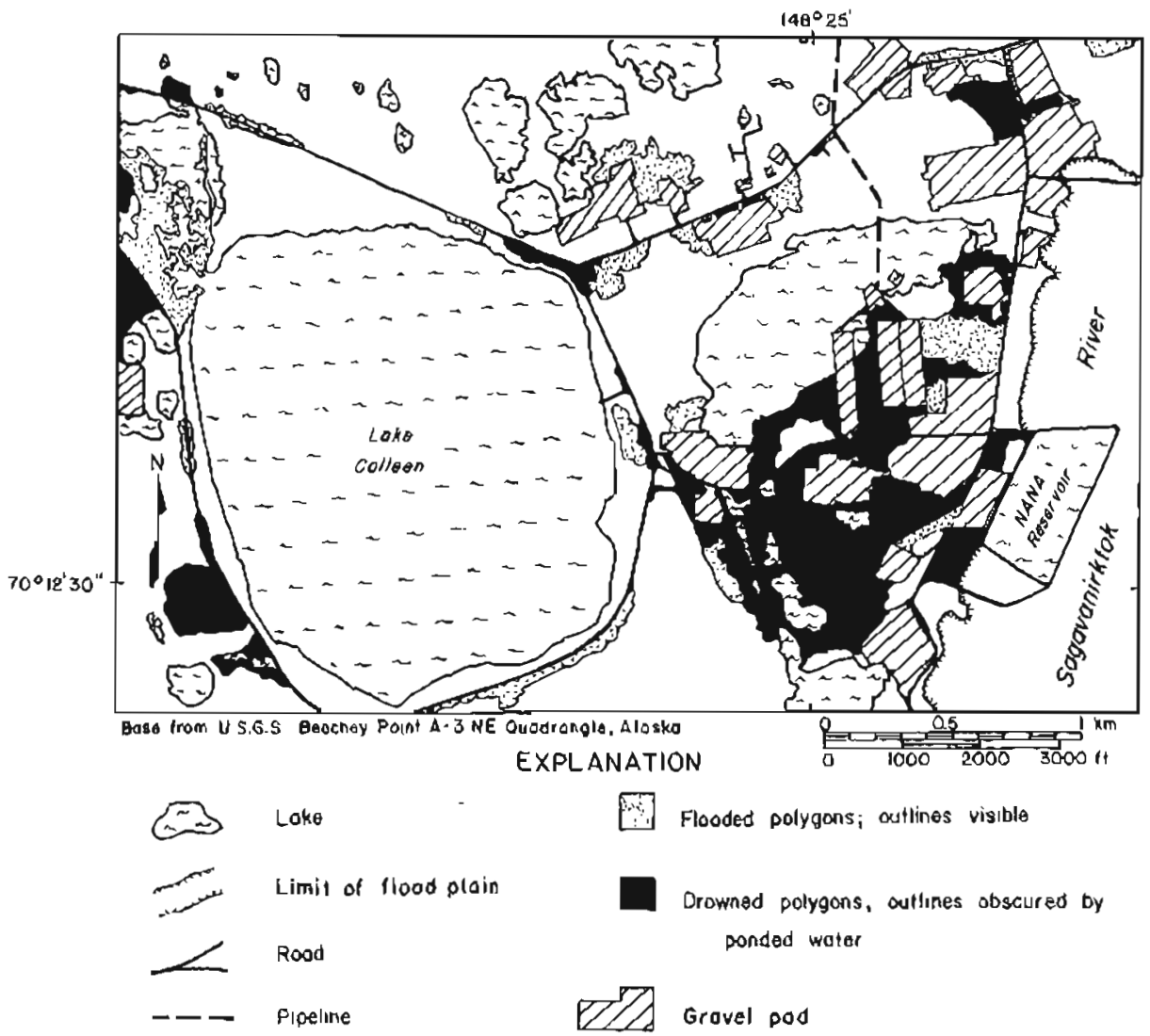

Figure 3. Extent of inundated polygons in part of Prudhoe Bay oil field, Alaska, July 13, 1979. 
frost (R.G. Updike, pers. comm., 1980). Because the fill has a greater insulating value than the original active layer, the permafrost table rises (fig. 4). An imperme. able barrier of permatrost is then created within the fill (Muller, 1945), which obstructs the flow of water, forcing it to the surface (Federal Energy Regulatory Commission, 1979; Curran and Etter, 1976). This is the probable mechanism for ponding of water adjacent to gravel pads and roads in the Pruahoe Bay area.

\section{EFFECTS OF OBSTRUCTION OF GROUND-WATER FLOW}

Curran and Etter (1976) suggest that damming of suprapermaliost ground water by the frozen impermeable barrier beneath the roadway can cause ground icings. When seasonal frost penetrates the saturated active layer, water expelled to the ground surface freezes in layers. They suggest various measures for mitigating the icing problems, including deliberately creating icings away from the road.

Ponded water warms the underlying permafrost. Lakes less than $2 \mathrm{~m}$ deep freeze to the bottom each year and are underlain by a seasonally thawed zolle 0.3 to $0.7 \mathrm{~m}$ thick. Permafrost temperatures at depth under these shallow lakes ate up to $3^{\circ} \mathrm{C}$ warmer than tempera. tures under the surtounding tundra (Brewer, 1958b). Lakes deeper than $2 \mathrm{~m}$ do not freeze to the bottom and develop a perennial thaw bulb (Seliman and others, 1975). As ponds expand, warming progresses downward and outward. Melting op ice-rich permafrost can ultimately cause subsidence of gravel fill adjacent to the ponds. If ponded water begins to flow laterally along gravel fill, both mechanical and thermal erosion can result (Ferrians and others, 1969).

\section{CONCLUSIONS}

Permafrost in gravel fill at the Prudhoe Bay oil field is damming suprapermafrost ground-water movement, as evidenced by ponded water adjacent to gravel roads and pads. The increased ponding coincides with the extent of fill deposited between 1973 and 1979. As more roads and pads are built, ground-water blockage will increase.

Ground-water damming and subsequent ponding may cause both ground icings and mechanical and thermal erosion of adjacent fill. Existing fill should be monitored for evidence of these problems. In new construction, elimination of ground-water blockage should be attempted before damming becomes a problem. Surface drainage has been facilitated by use of culverts, but ground-water drainage patterns are more difficult to determine. Potential damming problems require careful study in the early siages of development planning.

\section{ACKNOWLEDGMENTS}

James R. Riehle and Randall G. Updike provided helpful discussions and were very helpful in reviewing the manuscript. Constructive criticism was provided by Richard D. Reger. The 1973 photo mosaic was obtained by Updike from Sohio-8P, and the 1979 airphotos were obtained from ARCO.

\section{REFERENCES CITED}

Benson, C.S., Timmer, Robert, Holmgren, Biorn, Weller, Gurler, and Parrish. Soott, 1975, Observations on the seasonal snow cover and radiation climate at Prudboe Bay, Alaska during 1972, in Brown, Jerry, ed., Ecological investigations of the tundra biome in the

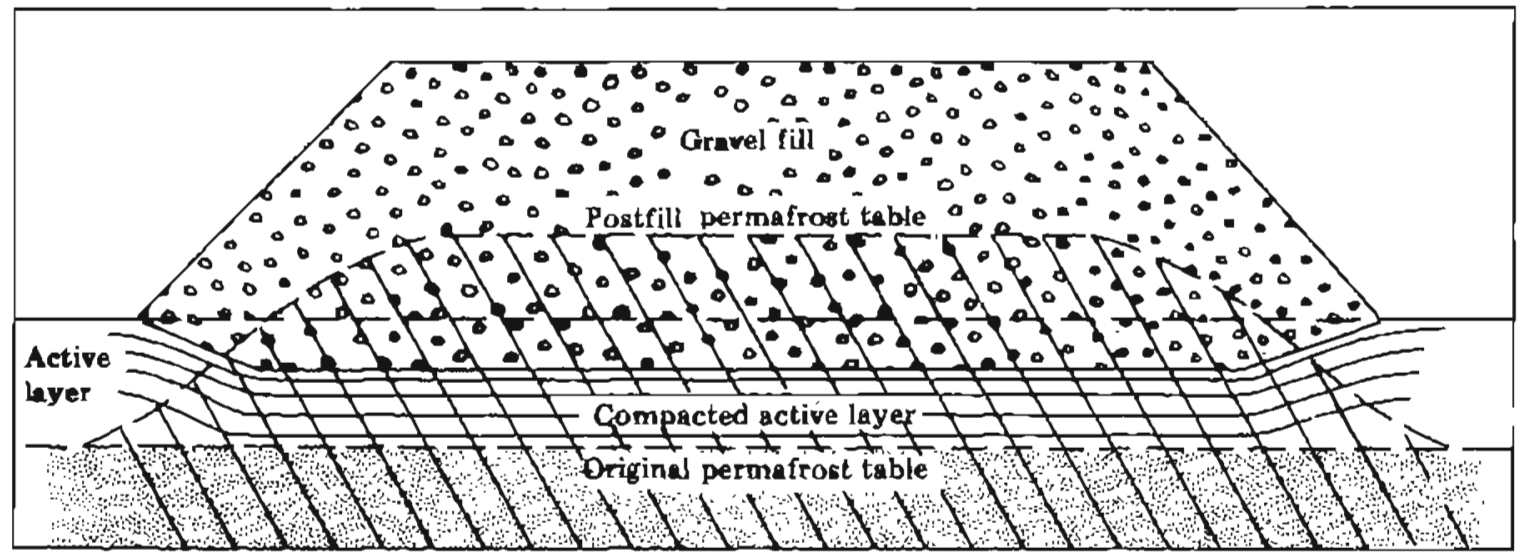

Figure 4. Effect on permafrost table of till with insulating value greater than that of original active layer (Erom Ferrians and others, 1969). 
Prudhoe Bay region, Alaska: Biological Papers of Univ. Alaska, Special Rept. 2, p. 13-62.

Brewer, M.C., 1958a, The thermal regime of an Aretic lake: Am. Geophys. Union Thans., v. 39, no. 2, p. $278-84$.

1958b, Some results of geothermal investigations of permafrost in northern Alaska: Am. Geophys. Union Trans., v. 39, no. 1, p. 19.26.

Curran, H.J.B., and Etter, H.M., 1976, Environmental design for northern road developments: Environinent. Canada, Environmental Protection Service, Environmental Impact and Assersment Rept. EPS-8.EC-76-3, $45 \mathrm{p}$.

Federal Energy Regulatory Commission, 1979, Construction and operation of a sales gas conditioning facility at Prudhoe Bay, Alaska: Prudhoe Bay Project Draft EIS, Northwestern Natural Gas Transportation Co. Docket CP78-123.

Ferrians, O.J., JY., Kachadoorian, Reuben, and Greene, G.W., 1969, Permafrost and related engineering problems in Alaska: U.S. Geol. Survey Prof. Paper 678. $37 \mathrm{p}$.
Morgridge, D.L., and Smith, W.B., Jr., 1972, Geology and discovery of Prudhoe Bay Field, eastern Arctic Slope, Alaska, in Stratigraphic oil and gas fields classificrtion, exploration methods and case histories (R.E. King, ed.): Am. Assoc. Petroleum Geologists Mem. 16, p. 489-501.

Mullex, S.W., 1945, Permafrost or permanently frozen ground and related engineering problems: U,S. Army Office Chief of Engineers, Military Intelligence Div. Strat. Eng. Study Spec. 62, 2d ed., 231 p. (Repr. 1947, Ann Arbor, Mich., J.W. Edwards).

Pèwè, T.L., 1966, Ice wedges in Alaska. Classification, distribution, and elimatic significance: Permafrost International Conf., Lafayette, Ind, 1963, Proc., Natl. Research Council Pub. 1287, p. 76.81

Sellman, P.V., Brown, Jerry, Lewellen, R.I., McKim, H.L., and Merry, C.J., 1975, The classification and geomorphic implications of thaw lakes on the Arctic Coastal Plain, Alaska: U.S. Army Materiel Command Cold Regions Research and Eng. Lab. Research Rept. $344,21 \mathrm{p}$. 